\title{
Seasonal variation in vertical volatile compounds air concentrations within a remote hemiboreal mixed forest
}

\author{
S. M. Noe, K. Hüve, Ü. Niinemets, and L. Copolovici \\ Department of Plant Physiology, Institute of Agricultural and Environmental Sciences, Estonian University of Life Sciences, \\ Kreutzwaldi 1, 51014 Tartu, Estonia
}

Correspondence to: S. M. Noe (steffen.noe@emu.ee)

Received: 21 December 2010 - Published in Atmos. Chem. Phys. Discuss.: 12 May 2011

Revised: 28 March 2012 - Accepted: 13 April 2012 - Published: 3 May 2012

\begin{abstract}
The vertical distribution of ambient biogenic volatile organic compounds (BVOC) concentrations within a hemiboreal forest canopy was investigated over a period of one year. Variability in temporal and spatial isoprene concentrations, ranging from 0.1 to $7.5 \mu \mathrm{g} \mathrm{m}^{-3}$, can be mainly explained by biogenic emissions from deciduous trees. Monoterpene concentrations exceeded isoprene largely and ranged from 0.01 to $140 \mu \mathrm{g} \mathrm{m}^{-3}$ and during winter time anthropogenic contributions are likely. Variation in monoterpene concentrations were found to be largest right above the ground and the vertical profiles suggest a weak mixing leading to terpene accumulation in the lower canopy. Exceptionally high values were recorded during a heat wave in July 2010 with very high midday temperatures above $30^{\circ} \mathrm{C}$ for several weeks. During summer months, monoterpene exceeded isoprene concentrations 6-fold and during winter 12-fold. During summer months, dominance of $\alpha$ pinene in the lower and of limonene in the upper part of the canopy was observed, both accounting for up to $70 \%$ of the total monoterpene concentration. During wintertime, $\Delta^{3}$ carene was the dominant species, accounting for $60 \%$ of total monoterpene concentration in January. Possible biogenic monoterpene sources beside the foliage are the leaf litter, the soil and also resins exuding from stems. In comparison, the hemiboreal mixed forest canopy showed similar isoprene but higher monoterpene concentrations than the boreal forest and lower isoprene but substantially higher monoterpene concentrations than the temperate mixed forest canopies. These results have major implications for simulating air chemistry and secondary organic aerosol formation within and above hemiboreal forest canopies. Possible effects of in-cartridge oxidation reactions are discussed as our measurement tech-
\end{abstract}

nique did not include oxidant scavenging. A comparison between measurements with and without scavenging oxidants is presented.

\section{Introduction}

Emissions of biogenic hydrocarbons from forest ecosystems are a dominant source of reduced organic gases to the atmosphere. They even exceed emissions of hydrocarbons by anthropogenic pollution and biomass burning. Biogenic emissions play important roles in determining the global, regional, and local atmospheric chemistry which, in turn, feeds back to the ecosystem (Arneth et al., 2010; Kulmala et al., 2004).

Losses of instantaneously emitted hydrocarbons such as terpenes due to oxidation processes throughout the canopy height have been reported by several studies (Holzinger et al., 2005; Fuentes et al., 2007; Stroud et al., 2005). Especially if the canopy height and structure together with atmospheric turbulence is such that the residence time of air parcels within the canopy are comparable or greater than the lifetimes of BVOCs, chemical losses and deposition within the canopy lead to reduced above canopy fluxes (Fuentes et al., 2007; Karl et al., 2004; Strong et al., 2004). Effects of ozone, nitrogen oxides $\left(\mathrm{NO}_{\mathrm{x}}\right)$ and hydroxyl radical $(\mathrm{OH})$ on the vertical distribution of BVOCs or vice-versa have been also assessed by means of 1-D canopy chemistry models including atmospheric transport terms (Forkel et al., 2006; Fuentes et al., 2007; Karl et al., 2004; Stroud et al., 2005; Strong et al., 2004). These studies mostly conclude that the discrepancy between upscaled leaf level BVOC emission fluxes 
and canopy scale flux measurements are due to the within canopy chemistry that lead to a reduction in above canopy BVOC flux to the boundary layer. Monoterpene uptake by leaves of deciduous tree species under high ambient concentrations occurs and leads to altered temporal behavior of total monoterpene fluxes. Such processes have been described by Copolovici et al. (2005) and Noe et al. (2008).

Seasonal variations in isoprene and monoterpene emissions have been widely reported for a large variety of ecosystems and tree species (Holzinger et al., 2006; Hakola et al., 2003, 2009; Sabillón and Cremades, 2001; Mayrhofer et al., 2005) and also entered into emission models on various scales (Schurgers et al., 2009; Guenther et al., 2006). In some cases only total monoterpene fluxes have been taken into account and $\alpha$-pinene is commonly used as a proxy to represent all monoterpenes. This is in contrast to the finding that monoterpenes have quite different atmospheric lifetimes (Atkinson et al., 1990; Atkinson, 2000; Lyubovtseva et al., 2005) due to differences in their chemical degradation which impact the subsequent processes such as secondary organic aerosol (SOA) formation ( $\mathrm{Ng}$ et al., 2008; Kanakidou et al., 2005; Spracklen et al., 2008).

Forest trees are exposed to a huge amount of biotic and abiotic stresses and environmental factors that lead to very heterogenous emission patterns of biogenic hydrocarbons (Niinemets, 2010a). Inclusion of process-based approaches, addressing such factors on larger scale emission fluxes of biogenic hydrocarbons have been reviewed recently ( $\mathrm{Ni}$ inemets et al., 2010d; Arneth et al., 2008; Arneth and Niinemets, 2010; Niinemets, 2010b). The findings of Stroud et al. (2005) and Karl et al. (2004) already led to an empirical term for the escape efficiency of biogenic hydrocarbons from forest canopies into the boundary layer. That escape efficiency has been included to the MEGAN framework (Guenther et al., 2006) to allow to scale biogenic hydrocarbon emissions to regional or global levels.

Estonia is located at the transition zone between the boreal and temperate biomes which characterizes the location of hemiboreal, mostly mixed, forests. Nilsson (1997) estimates the width of that transition zone over Eurasia to span at least over $600 \mathrm{~km}$ (Sweden) and even wider in Siberia (Russia). Given predictions on species diversity and their change under future climate in Scandinavia (Sætersdal et al., 1998) and the likely climatic impact on northern ecosystems (Intergovernmental Panel on Climate Change, 2007), it seems likely that the hemiboreal transition zone will move and enlarge to north. Until now only few studies have been pointed to the atmosphere-biosphere relations within that zone. The aim of our study was to give (1) an overview on the ambient isoprene and monoterpene concentrations within a remote hemiboreal mixed forest canopy to assess (2) the seasonal change and reveal variations in ambient concentrations due to the changes in environment and to study (3) the spatial heterogeneity of isoprene and monoterpene ambient concentrations within the canopy.

\section{Materials and methods}

\subsection{Site description}

The vertical VOC profiles were measured at a $20 \mathrm{~m}$ high tower located in the Järvselja Experimental Forest in southeast Estonia $\left(58^{\circ} 25^{\prime} \mathrm{N}, 27^{\circ} 46^{\prime} \mathrm{E}\right)$. The site is situated in the hemiboreal forest zone with a moderately cool and moist climate and is described in more detail by Noe et al. (2010). These transition zones spreading between the boreal and temperate climate zones are populated by conifer dominated mixed forests. In terms of air pollution the area in the vicinity of the measurement tower is characterized as a remote site. The distance to the next larger town (100000 inhabitants) is $55 \mathrm{~km}$ to north-east direction. There are no main transit roads passing a circle of about $50 \mathrm{~km}$ around the tower location.

The measurement site is dominated by Norway spruce (Picea abies (L.) Karst.) and as co-dominant species Silver Birch (Betula pendula Roth.) and Black Alder (Alnus gluti$n o s a \mathrm{~L}$.) in the upper canopy layer varying between 16-20 m. The presence of a suppressed tree layer with a mean height between $6-7 \mathrm{~m}$ is of particularly importance as it affects turbulent air flows within the stand. The soil is covered by a dense and rather species rich layer of ground vegetation and a moss layer that consists of several species. The site has a lowland character and is influenced by a high groundwater table and water logging due to the vicinity of Lake Peipsi. Especially in humid spots we found Sphagnum species which are typical for peat bogs.

The mean annual temperature varies between $4-6{ }^{\circ} \mathrm{C}$ and the annual precipitation between $500-750 \mathrm{~mm}$, about 40 $80 \mathrm{~mm}$ of the annual precipitation is snow. The length of the growing season (daily air temperature above $5^{\circ} \mathrm{C}$ ) averages between 170-180 days. Following the typical phenological pattern, bud break of the main deciduous tree species in the area is in the end of April. Foliation takes place about mid May and leaf senescence in mid October. The fluctuation in these phenological events is \pm 14 days.

The site had typically at midday $0.2-0.8$ ppbv $\mathrm{NO}_{\mathrm{x}}$ mixing ratios and the midday ozone mixing ratios ranged between $10-30 \mathrm{ppbv}$ with maximal midday mixing ratios of $60 \mathrm{ppbv}$ during some days in summer 2010.

\subsection{VOC sampling}

We conducted the sampling of VOC from ambient air on 6 heights $(0,4,8,12,16$, and $20 \mathrm{~m}$ above ground) over a year starting in October 2009 until September 2010 (Table 1). The days of sampling have been chosen such that we obtained samples in each season of the year at an air pressure above $1000 \mathrm{hPa}$ and clear sky. The measurements conducted in autumn and winter (October to April) were taken at one day. During spring and summer (May to September) there have been several days per month measured during campaigns and we chose one day that met the criteria given above. 
Table 1. Overview of the meteorological conditions on the days when VOC vertical profile sampling was conducted. All values are reported as hourly averages during the time of measurements and refer to the top of the measurement tower at $20 \mathrm{~m}$. The type of measurement conducted refers as follows $v=$ volatile sampling, $t=$ temperature measured on all heights, $l=$ light measured on all heights. The sampling was in all cases conducted under clear sky conditions.

\begin{tabular}{lcrrrr}
\hline $\begin{array}{l}\text { measurement } \\
\text { date }\end{array}$ & type & $\begin{array}{r}\text { wind } \\
\text { direction }\end{array}$ & $\begin{array}{r}\text { wind speed } \\
\left(\mathrm{m} \mathrm{s}^{-1}\right)\end{array}$ & $\begin{array}{r}\text { temperature } \\
\left({ }^{\circ} \mathrm{C}\right)\end{array}$ & $\begin{array}{r}\text { air pressure } \\
(\mathrm{hPa})\end{array}$ \\
\hline Oct 2009 & $v$ & $209^{\circ}$ & 3.7 & 7.8 & 1022.7 \\
Jan 2010 & $v$ & $56^{\circ}$ & 1.9 & -19.4 & 1042.7 \\
Apr 2010 & $v$ & $285^{\circ}$ & 1.1 & 8.2 & 1021.1 \\
May 2010 & $v$ & $61^{\circ}$ & 3 & 24.5 & 1012.5 \\
Jun 2010 & $v$ & $270^{\circ}$ & 1.5 & 24.3 & 1021.1 \\
Jul 2010 & $v, l$ & $167^{\circ}$ & 5.7 & 31.2 & 1006.5 \\
Aug 2010 & $v, t, l$ & $118^{\circ}$ & 2.6 & 25.2 & 1020.7 \\
Sep 2010 & $v$ & $193^{\circ}$ & 4 & 19.2 & 1013.2 \\
\hline
\end{tabular}

The samples were directly drawn into multibed stainless steel cartridges $(10.5 \mathrm{~cm}$ length, $3 \mathrm{~mm}$ inner diameter, Supelco, Bellefonte, PA, USA) filled with Carbotrap C 20/40 mesh (0.2 g), Carbopack C 40/60 mesh (0.1 g) and Carbotrap X 20/40 mesh (0.1 g) adsorbents (Supelco).

We used a total of three constant flow air sample pumps (1003-SKC, SKC Inc., Huston, TX, USA) and one multisample constant flow air sample pump (224-PCXR8, SKC Inc., Huston, TX, USA) that allows to draw four samples at the same time. Each sampling took $30 \mathrm{~min}$ with a flow of $200 \mathrm{ml} \mathrm{min}{ }^{-1}$ which concentrated a total of 61 of ambient air on the adsorbent. The samples were stored and cooled $\left(+5^{\circ} \mathrm{C}\right)$ until analysis which took place within 4 to $6 \mathrm{~h}$ after sampling. With this setup we were able to sample a total of four repetitions on each height within a time frame of 2$2.5 \mathrm{~h}$ around midday local winter time $(\mathrm{UTC}+2)$. In each sampling step, we collected all 6 heights and each time we changed the cartridges, we changed the direction of the sample inlet by $90^{\circ}$ leading to a full rotation of the samples over the total sampling period per day.

Several authors had reported possible biases in measurements due to oxidation reactions while sampling. The adsorbent material used plays a role and sample losses have been reported especially for Tenax adsorbents (Calogirou et al., 1996; Helmig, 1997; Pollmann et el., 2005) while carbon adsorbents are reported to have nearly $100 \%$ recovery for BVOCs (Ciccioli et al., 1984; Metts, 2007).

However, a total of 32 measurements (16 parallel measurements with and without ozone scrubber) were additionally conducted in September and October 2011 to assess possible effects of ozonolysis during the sampling procedure. The measurements were conducted above and inside the canopy, $20 \mathrm{~m}$ and $0 \mathrm{~m}$ above ground, using the same flows and sampling intervals as described before. We took parallel samples, one with and one without ozone scrubber, placed with a distance of $5 \mathrm{~cm}$ between their inlets above and within the canopy during one time interval of $30 \mathrm{~min}$. The ozone trapping system used is described by Sun et al. (2012) and based on the catalytic activity of $\mathrm{Cu}$ (II) compounds. During the additional measurements, ambient ozone mixing ratios were between 10-25 ppbv and were reduced below 1 ppbv by the trap system.

\subsection{Resin sampling}

For comparison with the volatile components found in the air space around tree trunks we took three samples of spruce resin from the stems of the trees surrounding the tower. The samples were taken at about $1 \mathrm{~m}$ heights on the stem of spruce trees at places that were exuding resin. The resin was picked using a small spruce stick and transferred into $8 \mathrm{ml}$ glass vials for transport and subsequent analysis.

\subsection{VOC analysis}

Adsorbent cartridges were analyzed with a combined Shimadzu TD20 automated cartridge desorber and Shimadzu 2010 Plus GC-MS instrument (Shimadzu Corporation, Kyoto, Japan) described previously (Copolovici et al., 2009; Toome et al., 2010).

For the analysis of the resin samples, $0.2 \mathrm{~g}$ resin was dissolved in $2 \mathrm{ml}$ hexane and extracted over $24 \mathrm{~h}$ at $4{ }^{\circ} \mathrm{C}$. The preparations were shaken at $4{ }^{\circ} \mathrm{C}$ for $30 \mathrm{~min}$ and then centrifuged at $10000 \mathrm{~g}$ for $5 \mathrm{~min}$. The supernatant was then filtered through two layers of no. 1 filter paper (Whatman, Kent, UK). Determination of the monoterpenes of the resin was achieved by GC-MS (Shimadzu 2010 Plus GC-MS, Shimadzu Corporation, Kyoto, Japan) and equipped with a Shimadzu AOC20 autoinjector/autosampler.

Separation of different compounds was achieved in a ZB$5 \mathrm{MS}$ capillary column $(30 \mathrm{~m}, 0.25 \mathrm{~mm}$ i.d., $0.25 \mu \mathrm{m}$ film thickness, Zebron, Phenomenex, Torrance, CA, USA). Injector temperature was set at $215^{\circ} \mathrm{C}$. Initial oven temperature was set at $40^{\circ} \mathrm{C}$, held for $1 \mathrm{~min}$; ramped at $5^{\circ} \mathrm{C} \mathrm{min}{ }^{-1}$ up to $200^{\circ} \mathrm{C}$, held for $1 \mathrm{~min}$; ramped at $10^{\circ} \mathrm{C} \mathrm{min}^{-1}$ up to $220^{\circ} \mathrm{C}$ and held for 5 min. Helium (purity $99.9999 \%$, Elmer Messer Gaas AS, Tallinn, Estonia) was employed as carrier gas with 
a constant flow of $0.74 \mathrm{ml} \mathrm{min}^{-1}$. The mass spectrometer was operated in electron-impact mode (EI) at $70 \mathrm{eV}$, in the scan range $m / z \quad 30-400$, the transfer line temperature was set at $240^{\circ} \mathrm{C}$ and ion-source temperature at $150^{\circ} \mathrm{C}$. Compounds were identified by use of the NIST spectral library and based on retention time identity with the authentic standard (GC purity, Sigma-Aldrich, St. Louis, MO, USA). The absolute concentrations of isoprene, monoterpenes and lipoxygenase (LOX) pathway products were calculated based on an external authentic standard consisting of known amount of VOCs.

\subsection{Auxiliary measurements}

Beside the main task of assessing vertical VOC profiles throughout the canopy and over the seasons, we measured, predominantly under summer conditions, also ambient temperature, light and $\mathrm{CO}_{2}$ profiles throughout the canopy.

Temperature measurements have been conducted using a radiation shielded thermocouple sensor that was connected to a thermocouple reader (Comark KM330, Comark Instruments, Hitchin, Hertfordshire, UK). When temperature was measured, the sensor was placed beside the sampling pump and during the sampling time, three to four values of temperature were recorded. As that was conducted by every change of the cartridges, a maximum of 12-16 temperature measurements per height over sampling period were achieved.

Quantum flux density (PPFD) was measured with a LI190SA quantum sensor (LiCor, Lincoln, NE, USA). On each height, PPFD was measured in shade conditions and in full sunlight, if available. At least 5 measurements were taken during the whole BVOC sampling interval at different locations near the sampling pump and the data averaged.

To assess the ambient $\mathrm{CO}_{2}$ mixing ratios throughout the canopy, a closed path infrared gas analyzer (IRGA) (LI7000, Li-Cor, Lincoln, NE, USA) was used. Sample air was drawn from each height by Teflon pipes passing a filter (Acro50, Gelman, Ann Arbor, MI, USA) and the IRGA. An air flow of $101 \mathrm{~min}^{-1}$ was provided by a vacuum pump (Samos SB 0080 D, Busch Vakuumteknik Oy, Vantaa, Finland). Each height level was measured with a 10 minute interval for 3 hours extending over the time of BVOC sampling. We recorded the values every minute and values have been averaged the values for each height separately over the sampling period.

Horizontal wind speed was measured with two 3-D sonic anemometers (CSAT3, Campbell Scientific, 168 Logan, UT, USA; Metek USA-1, Metek GmbH, Elmshorn, Germany) which have been installed on top of the tower at a height of $20 \mathrm{~m}$ above ground and on a mast at a height of $2 \mathrm{~m}$ above forest floor for continuous eddy covariance measurements at the site.

The ozone was detected using a Thermo Model 49i ozone analyzer and $\mathrm{NO} / \mathrm{NO}_{2} / \mathrm{NO}_{\mathrm{x}}$ were detected with a Thermo Model 42i (both Thermo Scientific, Waltham,MA, USA).

\subsection{Comparison of parallel measurements with and without ozone removal}

In order to asses a possible bias by sampling reactive trace gas compounds such as terpenes in a polluted atmosphere including ozone we applied the method of Bland and Altman (1999) for paralleled samples with and without ozone removal. The first step is to plot the parallel measured values against each other and the one-to-one line $(y=x)$. The distribution of the data points around the identity line allow a visual assessment of outliers and bias in the data.

The quantification of a relative bias in the parallel measured data is done by plotting the difference

$d=\left(X_{s}-X_{n}\right)$,

of the measurement conducted with ozone removal $X_{s}$ and without ozone removal $X_{n}$ against the arithmetic mean

$\bar{X}=\frac{X_{s}+X_{n}}{2}$,

for each pair $X_{s}, X_{n}$ measured in parallel. Assuming a normal distribution of the differences, the $95 \%$ confidence interval limits for bias are calculated from the mean difference $\bar{d}$ which is the relative bias and the standard deviation of the differences $s_{\mathrm{d}}$ as

$\bar{d}+1.96 s_{\mathrm{d}}$ and $\bar{d}-1.96 s_{d}$.

A linear model regression on the data set $\left\{d_{i}, \overline{X_{i}}\right\}$ with $i \in N$ where $N$ denote the sample size can be used to assess if the bias is constant or proportional and therefore depend on the range of the measurement. Constant bias is achieved when the slope of the linear model equals zero and a proportional bias if the slope does not equal to zero.

As we assume a normal distribution of the differences between the samples a measure for the precision of the estimated relative bias can be given by calculating the variance of the differences scaled to the sample size $s_{d}^{2} / N$. The precision for the limits of agreement ( $95 \%$ confidence interval) is then given by

$\operatorname{Var}\left(\bar{d} \pm 1.96 s_{d}\right)=\left(\frac{1}{N}+\frac{1.96^{2}}{2(N-1)}\right) s_{d}^{2}$

and reflects to what extend the random error influences the location of the $95 \%$ boundaries around the relative bias $\bar{d}$. Dividing the precision of the limits of agreement by the standard deviation of the differences allows us to give a relative estimate of the contribution of random error to the bias.

To allow a statement on the relation between the bias and ozone mixing ratios during the sampling, we plot the difference $d$ against the measured half hour mean ozone mixing ratios. 
Table 2. Seasonal ambient isoprene and plant stress signal compounds (Z)-3-hexenol and 1-hexanol (LOX) measured on six heights throughout the canopy. Values are given as means and standard deviations (SD) in $\mu \mathrm{g} \mathrm{m}^{-3}$.

\begin{tabular}{|c|c|c|c|c|c|c|c|c|c|c|c|c|c|c|c|c|}
\hline \multirow{2}{*}{$\begin{array}{c}\text { height } \\
{[\mathrm{m}]}\end{array}$} & \multicolumn{2}{|c|}{ Oct 2009} & \multicolumn{2}{|c|}{ Jan 2010} & \multicolumn{2}{|c|}{ Apr 2010} & \multicolumn{2}{|c|}{ May 2010} & \multicolumn{2}{|c|}{ Jun 2010} & \multicolumn{2}{|c|}{ Jul 2010} & \multicolumn{2}{|c|}{ Aug 2010} & \multicolumn{2}{|c|}{ Sep 2010} \\
\hline & mean & SD & mean & SD & mean & SD & mean & SD & mean & SD & mean & $\mathrm{SD}$ & mean & SD & mean & SD \\
\hline \multicolumn{17}{|c|}{ isoprene } \\
\hline 16 & 0.2 & 0.01 & 0.3 & 0.02 & 0.09 & 0.04 & 0.4 & 0.09 & 2.2 & 0.07 & 4.5 & 0.5 & 2.2 & 0.08 & 0.5 & 0.1 \\
\hline 12 & 0.2 & 0.06 & 0.3 & 0.02 & 0.1 & 0.04 & 0.3 & 0.03 & 1.8 & 0.01 & 4.4 & 0.3 & 2.5 & 0.23 & 0.4 & 0.3 \\
\hline 8 & 0.2 & 0.05 & 0.4 & 0.2 & 0.1 & 0.03 & 0.4 & 0.2 & 1.9 & 0.2 & 5.7 & 2.3 & 3.0 & 0.3 & 0.6 & 0.2 \\
\hline \multicolumn{17}{|c|}{ (Z)-3-hexenol } \\
\hline 20 & 0.06 & 0.03 & 0.08 & 0.05 & 0.05 & 0.004 & 0.04 & 0.02 & 0.1 & 0.07 & 1.3 & 1.0 & 0.3 & 0.3 & 0.1 & 0.04 \\
\hline 16 & 0.05 & 0.03 & 0.1 & 0.04 & 0.2 & 0.03 & 0.02 & 0.006 & 0.1 & 0.07 & 2.8 & 4.3 & 0.2 & 0.1 & 0.1 & 0.06 \\
\hline 12 & 0.06 & 0.02 & 0.1 & 0.03 & 0.3 & 0.08 & 0.04 & 0.01 & 0.3 & 0.2 & 0.1 & 0.07 & 0.1 & 0.04 & 0.1 & 0.07 \\
\hline 8 & 0.1 & 0.06 & 0.2 & 0.08 & 0.2 & 0.05 & 0.1 & 0.07 & 0.3 & 0.08 & 0.3 & 0.3 & 0.08 & 0.005 & 0.2 & 0.05 \\
\hline 20 & 0.02 & 0.008 & 0.04 & 0.02 & 0.03 & 0.001 & 0.005 & 0.002 & 0.02 & 0.01 & 2.1 & 1.4 & 0.5 & 0.7 & 0.05 & 0.01 \\
\hline 16 & 0.02 & 0.004 & 0.05 & 0.003 & 0.1 & 0.05 & 0.005 & 0.002 & 0.04 & 0.01 & 3.4 & 5.4 & 0.3 & 0.2 & 0.04 & 0.03 \\
\hline 12 & 0.02 & 0.01 & 0.05 & 0.01 & 0.2 & 0.1 & 0.005 & 0.004 & 0.06 & 0.009 & 0.09 & 0.02 & 0.04 & 0.004 & 0.02 & 0.02 \\
\hline 8 & 0.03 & 0.01 & 0.06 & 0.006 & 0.1 & 0.04 & 0.04 & 0.05 & 0.08 & 0.03 & 0.09 & 0.06 & 0.05 & 0.02 & 0.3 & 0.2 \\
\hline 4 & 0.03 & 0.02 & 0.05 & 0.04 & 0.1 & 0.05 & 0.2 & 0.03 & 0.04 & 0.007 & 0.08 & 0.03 & 0.6 & 1.1 & 0.07 & 0.04 \\
\hline 0 & 0.04 & 0.03 & 0.04 & 0.03 & 0.02 & 0.004 & 0.22 & 0.23 & 0.04 & 0.009 & 0.06 & 0.03 & 0.02 & 0.006 & 0.05 & 0.005 \\
\hline
\end{tabular}

\section{Results}

\subsection{Environmental factors}

Terpene concentrations in ambient air rely on the emissions from plants as sources and on the chemical composition and oxidative state of the atmosphere determining the sink defined by chemical reactions. Figure 1 shows an example during summer of key environmental drivers that affect both, the source and the sink of terpenes in the atmosphere. The temperature showed a typical pattern for the mid of a clear and sunny day with higher temperatures on top of the canopy and lower ones within the forest. An interesting effect was the outcome, that the variation within that parameter is larger on top of the canopy and directly above the forest floor. The light gradient showed the expected picture that the highest radiative input into the system is at the top of the canopy, were most leaves and needles are located and quickly decreases within the canopy. Below $8 \mathrm{~m}$ height PPFD remain below $100 \mu \mathrm{mol} \mathrm{m} \mathrm{m}^{-2} \mathrm{~s}^{-1}$. Between $12 \mathrm{~m}$ to $16 \mathrm{~m}$ we found the largest variation of the radiative energy while at the top of the canopy the variation is again small. The carbon dioxide $\left(\mathrm{CO}_{2}\right)$ gradient with concentrations at lower levels increasing well above ambient air concentrations is an indicator for reduced mixing of air during summer months, as is indicated also by the variation in horizontal wind speed (Fig. 2). The
$\mathrm{CO}_{2}$ accumulation in the lower parts of the understory is fed by soil and ground vegetation being a net source of carbon.

\subsection{BVOC overview}

We found a variety of reactive VOC species in the ambient air measured throughout the canopy. The monoterpenes $\alpha$-pinene, $\Delta^{3}$-carene, and limonene dominated the ambient concentrations (Figs. 3 and 5) and further $\beta$-pinene, camphene and $\alpha$-thujene were detected. From the shorter chained hydrocarbons, isoprene was detected as well as 1-hexanol and $(Z)-3$-hexenol. The latter both likely originated from the plants LOX pathway and typically indicate plant responses to environmental stress factors. During the warm summer months, the trees are likely to face several stresses such as heat, drought and high light (Niinemets, 2010a; Turtola et al., 2003). During June, July and August 2010 we also detected the sesquiterpenes $\gamma$-muurolene, $\alpha$-longifolene, $\beta$ caryophyllene, copaene, $\alpha$-cedrene, and $(E, E)$ - $\alpha$-farnesene in ambient air with their highest abundance in the upper canopy. Table 5 compiles the total ambient sesquiterpene concentrations together.

\subsection{Seasonal and spatial variation}

Isoprene and monoterpenes showed a large variability over the whole year (Fig. 3, Tables 2 and 3). The mean values of isoprene varied between $0.1 \mu \mathrm{g} \mathrm{m}^{-3}$ and $7.5 \mu \mathrm{g} \mathrm{m}^{-3}$ with 
Table 3. Seasonal ambient monoterpene concentrations measured on six heights throughout the canopy. The values represent the mean and standard deviation (SD) in $\mu \mathrm{g} \mathrm{m}^{-3}$.

\begin{tabular}{|c|c|c|c|c|c|c|c|c|c|c|c|c|c|c|c|c|}
\hline \multirow{2}{*}{$\begin{array}{c}\text { height } \\
{[\mathrm{m}]}\end{array}$} & \multicolumn{2}{|c|}{ Oct 2009} & \multicolumn{2}{|c|}{ Jan 2010} & \multicolumn{2}{|c|}{ Apr 2010} & \multicolumn{2}{|c|}{ May 2010} & \multicolumn{2}{|c|}{ Jun 2010} & \multicolumn{2}{|c|}{ Jul 2010} & \multicolumn{2}{|c|}{ Aug 2010} & \multicolumn{2}{|c|}{ Sep 2010} \\
\hline & mean & SD & mean & SD & mean & SD & mean & SD & mean & $\mathrm{SD}$ & mean & $\mathrm{SD}$ & mean & SD & mean & SD \\
\hline \multicolumn{17}{|c|}{$\alpha$-thujene } \\
\hline 20 & 0.016 & 0.02 & 0.009 & 0.001 & 0.003 & 0.002 & 0.01 & 0.01 & 0.033 & 0.03 & 0.24 & 0.3 & 0.082 & 0.06 & 0.11 & 0.06 \\
\hline 16 & 0.007 & 0.004 & 0.02 & 0.02 & 0.2 & 0.1 & 0.003 & 0.001 & 0.11 & 0.1 & 0.19 & 0.2 & 0.033 & 0.01 & 0.14 & 0.09 \\
\hline 12 & 0.022 & 0.02 & 0.02 & 0.003 & 0.087 & 0.016 & 0.01 & 0.01 & 0.48 & 0.2 & 0.036 & 0.02 & 0.008 & 0.004 & 0.14 & 0.04 \\
\hline 8 & 0.003 & 0.003 & 0.021 & 0.02 & 0.16 & 0.09 & 0.088 & 0.09 & 0.63 & 0.5 & 0.023 & 0.02 & 0.01 & 0.006 & 0.19 & 0.06 \\
\hline 4 & 0.032 & 0.05 & 0.02 & 0.002 & 0.094 & 0.05 & 0.045 & 0.04 & 0.56 & 0.2 & 0.042 & 0.02 & 0.32 & 0.04 & 0.24 & 0.04 \\
\hline 0 & 0.045 & 0.07 & 0.01 & 0.002 & 0.003 & 0.005 & 0.12 & 0.06 & 0.93 & 0.2 & 0.59 & 0.5 & 0.36 & 0.09 & 0.19 & 0.04 \\
\hline \multicolumn{17}{|c|}{$\alpha$-pinene } \\
\hline 20 & 0.4 & 0.2 & 0.2 & 0.08 & 0.06 & 0.01 & 0.2 & 0.08 & 0.7 & 0.3 & 1.5 & 0.5 & 0.6 & 0.3 & 0.7 & 0.5 \\
\hline 16 & 0.3 & 0.06 & 0.6 & 0.5 & 5.2 & 1.9 & 0.02 & 0.003 & 0.8 & 0.6 & 2.2 & 0.9 & 0.6 & 0.1 & 0.3 & 0.1 \\
\hline 12 & 0.7 & 0.5 & 0.2 & 0.1 & 5.7 & 0.7 & 0.07 & 0.09 & 1.5 & 0.2 & 1.6 & 0.3 & 0.7 & 0.2 & 0.6 & 0.5 \\
\hline 8 & 0.4 & 0.3 & 0.10 & 0.06 & 5.2 & 1.7 & 3.1 & 2.6 & 2.3 & 1.7 & 1.4 & 0.5 & 1.2 & 0.08 & 0.47 & 0.3 \\
\hline 4 & 0.94 & 1.1 & 0.2 & 0.005 & 5.8 & 0.9 & 5.6 & 2.7 & 2.2 & 1.9 & 1.8 & 0.8 & 10.5 & 16.2 & 1.3 & 0.5 \\
\hline 0 & 1.9 & 1.0 & 0.07 & 0.02 & 2.5 & 0.8 & 9.5 & 6.4 & 23.2 & 1.3 & 7.5 & 6.5 & 5.3 & 0.5 & 4.6 & 1.4 \\
\hline \multicolumn{17}{|c|}{$\beta$-pinene } \\
\hline 20 & 0.06 & 0.03 & 0.06 & 0.04 & 0.05 & 0.02 & 0.04 & 0.009 & 0.3 & 0.2 & 16.9 & 16.5 & 1.4 & 2.1 & 0.09 & 0.05 \\
\hline 16 & 0.09 & 0.01 & 0.09 & 0.04 & 0.6 & 0.2 & 0.002 & 0.002 & 0.4 & 0.5 & 1.3 & 0.8 & 1.4 & 1.7 & 0.04 & 0.02 \\
\hline 12 & 0.09 & 0.01 & 0.04 & 0.02 & 0.6 & 0.2 & 0.07 & 0.08 & 0.4 & 0.3 & 0.4 & 0.2 & 0.1 & 0.08 & 0.2 & 0.1 \\
\hline 8 & 0.2 & 0.08 & 0.07 & 0.01 & 0.7 & 0.4 & 0.4 & 0.3 & 0.6 & 0.4 & 0.3 & 0.08 & 0.2 & 0.03 & 0.09 & 0.02 \\
\hline 4 & 0.3 & 0.4 & 0.01 & 0.007 & 0.5 & 0.3 & 0.6 & 0.2 & 0.4 & 0.3 & 0.5 & 0.2 & 1.0 & 1.6 & 0.3 & 0.2 \\
\hline 0 & 0.3 & 0.2 & 0.07 & 0.02 & 0.2 & 0.1 & 0.9 & 0.6 & 1.9 & 0.2 & 0.9 & 0.7 & 0.4 & 0.1 & 0.5 & 0.1 \\
\hline \multicolumn{17}{|c|}{ camphene } \\
\hline 20 & 0.1 & 0.06 & 0.09 & 0.02 & 0.05 & 0.01 & 0.05 & 0.009 & 0.5 & 0.4 & 4.8 & 2.2 & 1.7 & 2.6 & 0.3 & 0.2 \\
\hline 16 & 0.1 & 0.04 & 0.1 & 0.03 & 0.3 & 0.07 & 0.03 & 0.02 & 0.2 & 0.07 & 1.8 & 1.7 & 1.4 & 1.1 & 0.3 & 0.2 \\
\hline 12 & 0.2 & 0.1 & 0.1 & 0.03 & 0.3 & 0.2 & 0.04 & 0.01 & 0.4 & 0.2 & 0.3 & 0.04 & 0.2 & 0.06 & 0.2 & 0.1 \\
\hline 8 & 0.2 & 0.1 & 0.1 & 0.04 & 0.3 & 0.1 & 0.4 & 0.3 & 0.4 & 0.1 & 0.5 & 0.06 & 0.3 & 0.08 & 0.2 & 0.03 \\
\hline 4 & 0.6 & 0.2 & 0.2 & 0.07 & 0.6 & 0.1 & 0.8 & 0.2 & 0.5 & 0.08 & 0.5 & 0.1 & 0.9 & 1.2 & 1.4 & 0.9 \\
\hline 0 & 0.6 & 0.3 & 0.08 & 0.008 & 0.6 & 0.2 & 1.8 & 1.7 & 4.5 & 2.1 & 1.4 & 1.2 & 1.3 & 0.2 & 0.9 & 0.2 \\
\hline \multicolumn{17}{|c|}{$\Delta^{3}$-carene } \\
\hline 20 & 0.4 & 0.2 & 0.6 & 0.4 & 0.1 & 0.02 & 0.4 & 0.3 & 0.6 & 0.5 & 30.8 & 20.6 & 1.8 & 1.2 & 0.5 & 0.3 \\
\hline 16 & 0.4 & 0.05 & 1.5 & 1.3 & 1.8 & 0.7 & 0.01 & 0.01 & 0.6 & 0.5 & 25.3 & 18.1 & 1.7 & 1.9 & 0.2 & 0.06 \\
\hline 12 & 0.5 & 0.2 & 0.3 & 0.04 & 1.8 & 0.3 & 0.2 & 0.3 & 1.6 & 1.6 & 1.4 & 1.5 & 0.2 & 0.08 & 0.5 & 0.3 \\
\hline 8 & 0.3 & 0.09 & 0.3 & 0.3 & 1.8 & 0.5 & 0.8 & 0.5 & 1.0 & 0.5 & 0.6 & 0.2 & 0.5 & 0.1 & 0.7 & 0.5 \\
\hline 4 & 0.8 & 0.6 & 0.6 & 0.2 & 1.8 & 0.5 & 1.3 & 0.9 & 1.4 & 1.7 & 0.9 & 0.2 & 2.5 & 4.3 & 0.5 & 0.08 \\
\hline 0 & 0.7 & 0.3 & 0.3 & 0.1 & 0.2 & 0.09 & 2.0 & 1.1 & 2.3 & 0.6 & 0.7 & 0.7 & 0.6 & 0.2 & 0.5 & 0.07 \\
\hline \multicolumn{17}{|c|}{ limonene } \\
\hline 20 & 0.5 & 0.2 & 0.4 & 0.2 & 0.2 & 0.06 & 0.8 & 1.0 & 1.4 & 1.3 & 86.3 & 39.7 & 40.6 & 24.9 & 0.7 & 0.5 \\
\hline 16 & 0.7 & 0.4 & 0.6 & 0.5 & 0.9 & 0.3 & 0.04 & 0.02 & 0.5 & 0.4 & 19.2 & 18.2 & 4.1 & 3.4 & 1.2 & 1.7 \\
\hline 12 & 1.1 & 0.6 & 0.2 & 0.02 & 1.0 & 0.3 & 0.3 & 0.2 & 2.2 & 2.9 & 0.7 & 0.06 & 0.2 & 0.08 & 1.0 & 0.9 \\
\hline 8 & 0.4 & 0.3 & 0.2 & 0.2 & 0.7 & 0.2 & 0.6 & 0.5 & 0.7 & 0.4 & 0.9 & 0.6 & 0.9 & 0.6 & 1.4 & 1.2 \\
\hline 4 & 4.5 & 6.4 & 0.5 & 0.2 & 1.3 & 0.5 & 1.5 & 0.6 & 1.6 & 1.9 & 1.2 & 0.5 & 3.4 & 5.6 & 1.7 & 1.2 \\
\hline 0 & 0.8 & 0.2 & 0.2 & 0.08 & 0.5 & 0.2 & 1.8 & 0.6 & 3.1 & 0.9 & 0.7 & 0.6 & 0.6 & 0.2 & 0.7 & 0.09 \\
\hline
\end{tabular}

lowest values in April 2010 and highest in July 2010. Mean values of the LOX pathway compounds varied substantially between $0.03 \mu \mathrm{g} \mathrm{m}^{-3}$ and $3.4 \mu \mathrm{g} \mathrm{m}^{-3}$ with highest values exclusively in July 2010 and on the topmost level of the canopy. The mean values of monoterpenes showed the largest variability spanning over five orders of magnitude starting below
$0.01 \mu \mathrm{g} \mathrm{m}^{-3}$ and reaching nearly $100 \mu \mathrm{g} \mathrm{m}^{-3}$. Highest values were found in July 2010 under exceptionally hot conditions (Table 1 and Fig. 3) reaching $140 \mu \mathrm{g} \mathrm{m}^{-3}$.

The vertical profiles of isoprene and monoterpenes are presented in the Figs. 3 and 4. For isoprene, we can clearly distinguish differences in observed concentration ranges in the 
Table 4. Comparison of the relative contribution of monoterpenes from several possible sources near the forest floor. Resin samples have been taken in September 2010.

\begin{tabular}{lrrrr}
\hline name & resin [\%] & spruce litter [\%] & pine litter [\%] & soil efflux [\%] \\
\hline$\alpha$-pinene & 34.84 & 38.62 & 58.67 & 59.06 \\
$\beta$-pinene & 35.38 & 4.83 & 4.59 & 3.79 \\
$\Delta^{3}$-carene & 13.91 & 2.07 & 27.04 & 25.91 \\
limonene & 14.8 & 11.03 & 0.51 & 0.24 \\
\hline & this work & Isidorov et al. (2010) & Isidorov et al. (2010) & Aaltonen et al. (2011) \\
\hline
\end{tabular}
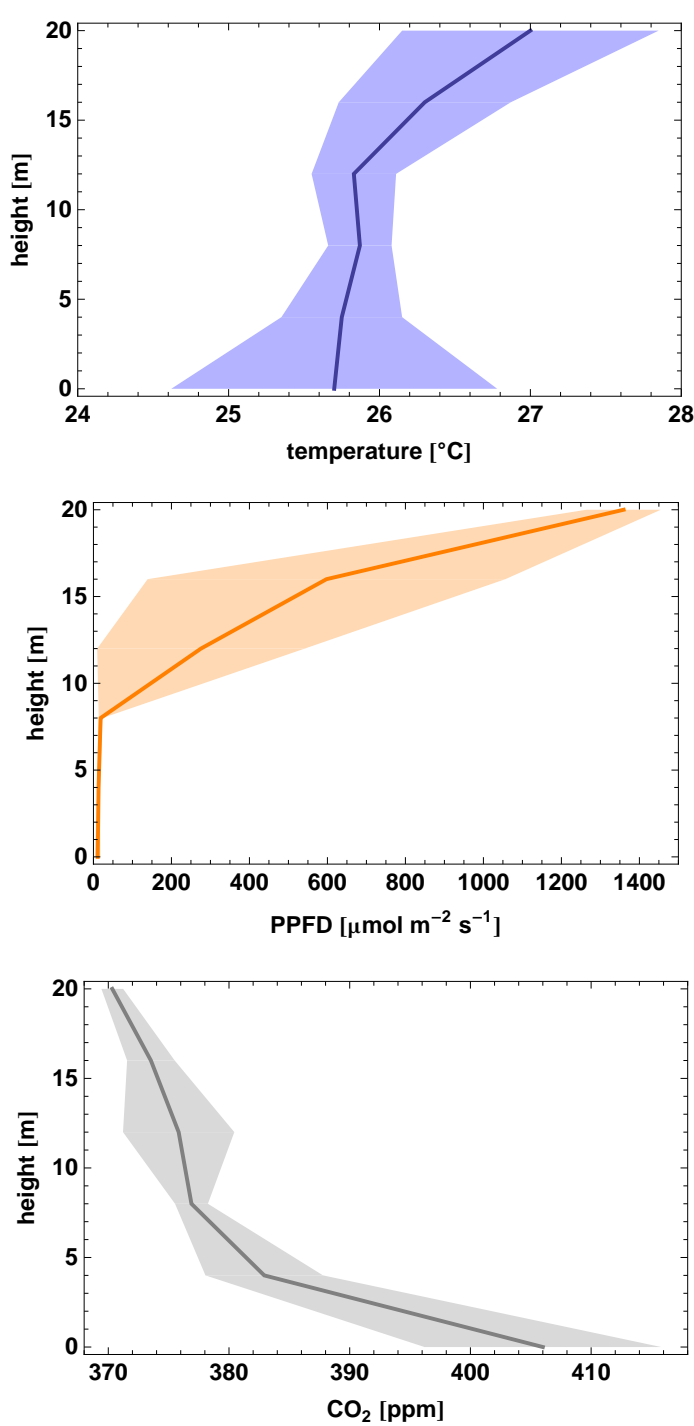

Fig. 1. Example of key environmental drivers for isoprene and monoterpene emissions from forest canopies in summer. Air temperature, quantum flux density (PPFD) and ambient $\mathrm{CO}_{2}$ mixing ratio have been measured on the 12 August 2010. The lines denote mean values and the shaded areas the standard deviations. Means have been averaged over the period of BVOC measurements.

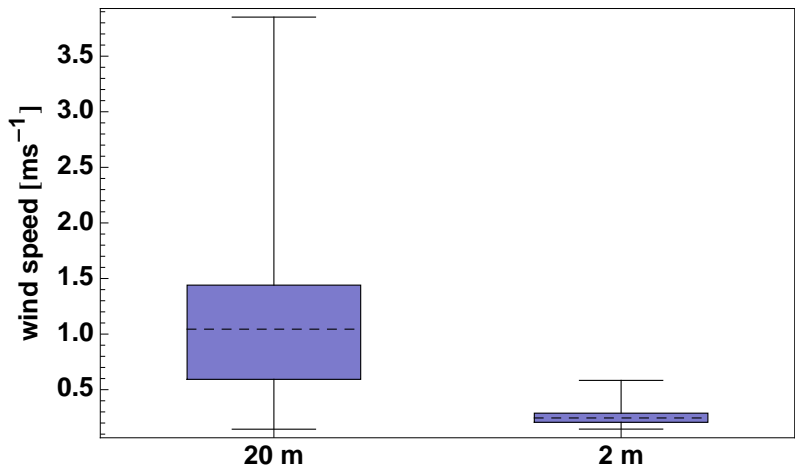

Fig. 2. Example for the variation of the wind speed above $(20 \mathrm{~m})$ and within the forest canopy $(2 \mathrm{~m})$. The data were measured during August 2009. The monthly median wind speed at $20 \mathrm{~m}$ height was $1.04 \mathrm{~m} \mathrm{~s}^{-1}$ and at $2 \mathrm{~m}$ height dropped to $0.25 \mathrm{~m} \mathrm{~s}^{-1}$. The boxes cover $50 \%$ of the data.

summer months (June to August) and the rest of the year. Comparing the height profile for each month, there was no clear pattern visible over the year (Fig. 3). While in June the highest concentrations were found on the topmost level of the canopy, the profile has changed considerably in August with higher concentrations found inside the canopy. In the case of total monoterpene concentrations, the situation is different. Excluding the exceptionally hot periods, the monoterpenes showed higher concentrations at $0 \mathrm{~m}$ and $4 \mathrm{~m}$ height over the whole year. Only during July 2010, when a long and exceptional hot period had occurred, the ambient monoterpene concentrations were dramatically increased at $16 \mathrm{~m}$ and $20 \mathrm{~m}$ height. The same, but much less prominent pattern was seen in August 2010, when the concentrations of monoterpenes were slightly larger on $20 \mathrm{~m}$ height than below (Fig. 3).

\subsection{Whole year canopy profile}

A more general pattern was obtained by combing the measurements per height over the whole year. Figure 4 shows the variation of isoprene and total monoterpene concentrations profiles found. Isoprene median concentrations were found to range between $0.33 \mu \mathrm{g} \mathrm{m}^{-3}$ and $0.56 \mu \mathrm{g} \mathrm{m}^{-3}$. The outliers were caused by the measurements in July 2010 and the largest variation was found at $16 \mathrm{~m}$ height where the dynamics of the environmental drivers was largest. The 

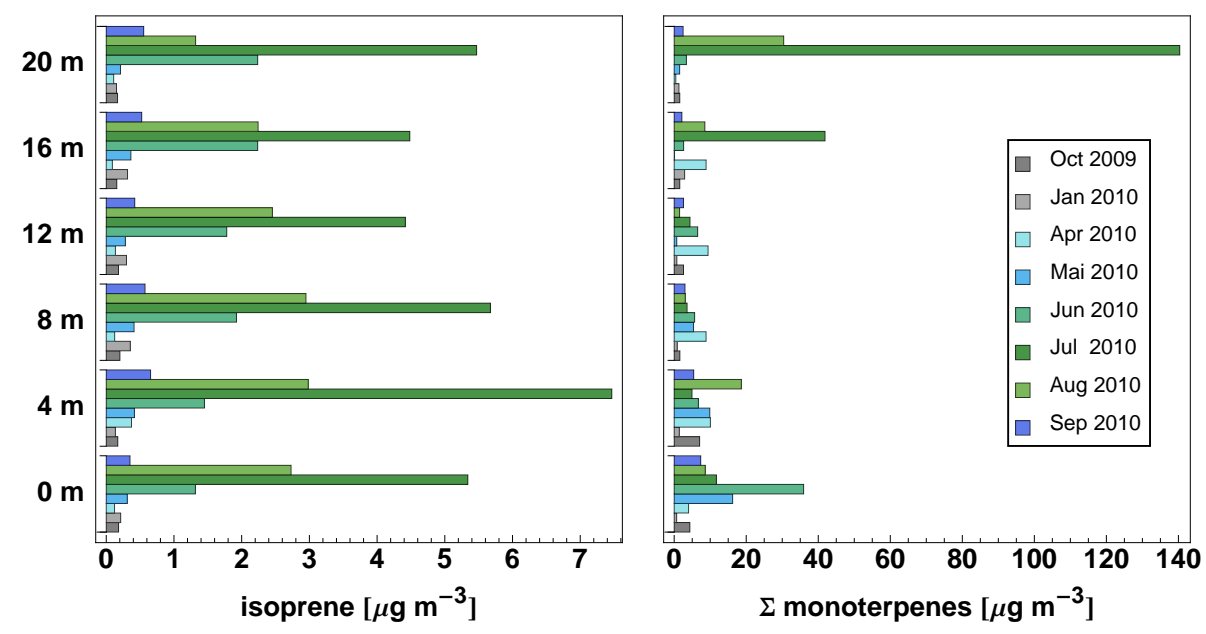

Fig. 3. Isoprene and total monoterpene concentrations measured in ambient air throughout the forest canopy and seasons. The sum of monoterpenes includes $\alpha$-thujene, $\alpha$ - and $\beta$-pinene, camphene, $\Delta^{3}$-carene and limonene (see also legend Fig. 5).
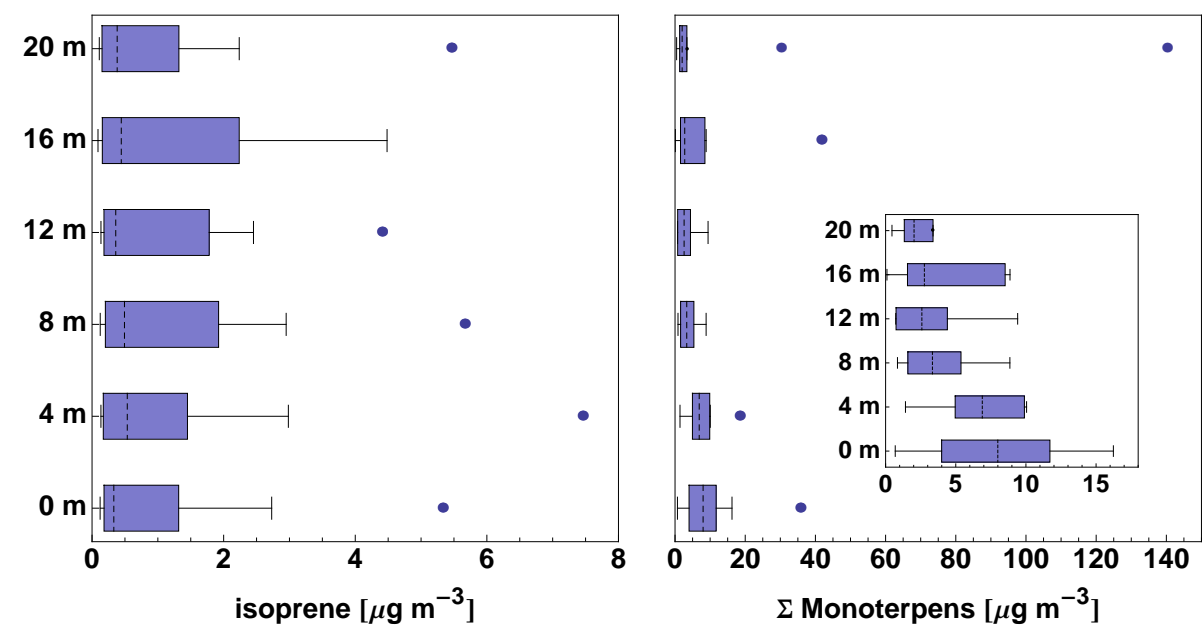

Fig. 4. Variation of isoprene and total monoterpene ambient air concentrations measured over the whole year. The boxes, ranging from the 0.25 to the 0.75 quartile, cover $50 \%$ of the data, the dashed lines denote the median concentration and the whiskers show the standard deviation of the data excluding far outliers. Outliers are given as dots and mark in both cases the measurements in July 2010 with exceptional high temperatures. The inset in the monoterpene plot show the shape of the boxes and the location of the median concentrations in detail.

monoterpene concentrations were found maximal in the forest understory between soil level and a height of $4 \mathrm{~m}$. Here as well, the outliers came from the measurements in July under high temperatures. The median monoterpene concentrations decreased from $8 \mu \mathrm{g} \mathrm{m}^{-3}$ at $0 \mathrm{~m}$ to $2 \mu \mathrm{g} \mathrm{m}^{-3}$ at $20 \mathrm{~m}$ height and the largest variability over the year was found at $0 \mathrm{~m}$ and $16 \mathrm{~m}$ (Fig. 4).

\subsection{Relative contribution by monoterpene species}

To assess changes in the contribution of several monoterpene species emitted, we normalized the total monoterpene concentration to one and expressed each monoterpene by its relative contribution (Fig. 5). These relative contributions showed as well a gradient over the canopy. While near to the forest floor, $\alpha$-pinene was the most abundant species, we found limonene dominating on top of the canopy for most times of the year, indicative of different sources contributing to individual monoterpene species. $\Delta^{3}$-carene showed the smallest fractional contribution to the total monoterpene concentrations at $0 \mathrm{~m}$ for the most times measured and its contribution was growing to top of the canopy. We assumed that the relative share of monoterpenes inside spruce resin does not change fast in time if already exuded from the stem. Our finding (Table 4) revealed that compared to spruce litter, the share of $\alpha$-pinene and limonene matched well while $\beta$-pinene and $\Delta^{3}$-carene are about a factor of 7 larger in the resin than in the spruce litter. Compared to the relative contribution of monoterpenes in ambient air (Fig. 5) the resins 

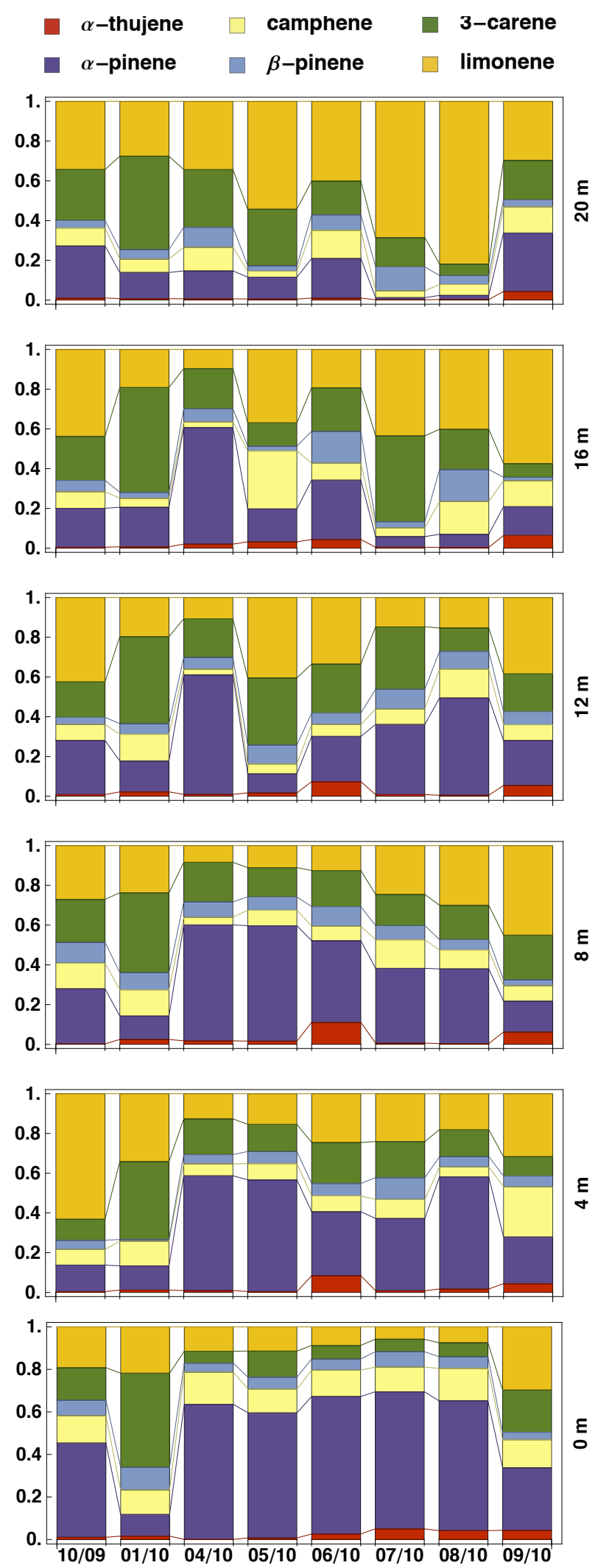

Fig. 5. Spatial and temporal relative contribution per monoterpene species scaled to the total monoterpene concentration. share of $\alpha$-pinene, $\Delta^{3}$-carene and limonene matched well the measurement in September 2010 at $0 \mathrm{~m}$ and $4 \mathrm{~m}$ height while $\beta$-pinene seems to be large as compared to ambient data. Overall, the heterogeneity and variability was larger at the top of the canopy than at the forest floor.

\subsection{Possible oxidant interferences on measurements}

Additional measurements to justify possible bias introduced by sampling without ozone removal from ambient atmosphere were conducted in 2011. These results are summarized in Figs. 6 and 7 as well as Table 7.

In the case of isoprene, we found a relative bias of $1.1 \%$ and the bias for monoterpenes was found to range between $-0.075-2.5 \%$. The only one negative value was found for $\beta$-pinene indicating that the measurement without ozone removal yielded in higher values. In the rest, the bias was positive, indicating a loss by sampling without ozone scrubber. The largest percentage was found for the most reactive monoterpene, limonene, and reached $2.5 \%$. Sesquiterpenes were not detected in any measurement using the ozone scrubber.

The precision of the estimates for the $95 \%$ confidence boundaries (Table 7, Fig. 6) can be used to assess the fraction of random error contributing to the deviation by the bias. The largest fraction was found for $\alpha$-pinene followed by $\Delta^{3}$ carene and limonene.

The linear trend lines in Fig. 6 revealed that only in the case of $\alpha$-pinene, the estimated relative bias can be graded independent from the ambient concentration. For other monoterpenes, isoprene and the combined monoterpene data, the slope (Table 7) is not near to zero and therefore the bias estimate depends on the measured concentration. In the case of isoprene, $\alpha$-thujene, and $\beta$-pinene the slope found to be positive and the bias is likely to increase with increasing ambient concentrations. In the case of camphene, $\Delta^{3}$-carene, limonene, and the combined monoterpene data the slope is negative and therefore it is likely that the estimate of the relative bias is smaller for higher ambient concentrations.

Correlations between relative bias and ambient ozone mixing ratios turned out to be small $|r|<0.4$ (Fig. 7). Negative correlation coefficients were found for isoprene, $\alpha$-thujene, and $\alpha$-pinene. Positive correlations for $\beta$-pinene, $\Delta^{3}$-carene, and limonene while for camphene and a combination of all monoterpenes no correlation was found.

The range of ambient concentrations can be as well assessed from Figure 6, where isoprene ranged between 0.05$0.4 \mu \mathrm{g} \mathrm{m}^{-3}$ and the monoterpenes between $0.01-1.5 \mu \mathrm{g} \mathrm{m}{ }^{-3}$. Given the results in Tables 2 and 3 the concentrations are in the same range as during the sampling in the year before. 

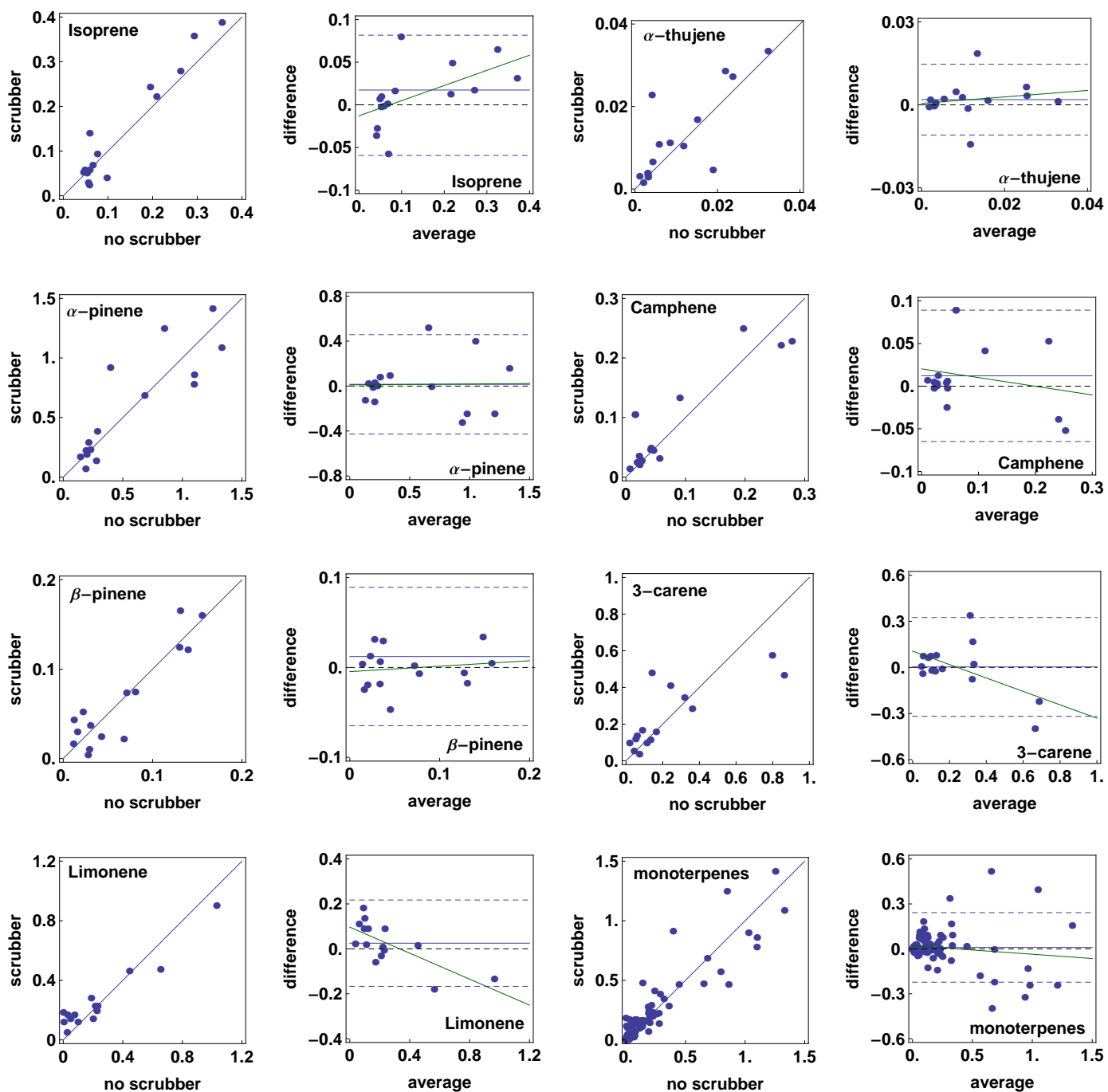

Fig. 6. Comparison between the two measurements conducted with (scrubber) and without (no scrubber) ozone removal according to the method of Bland and Altman (1999). For each one, isoprene, several monoterpenes and the combined dataset for monoterpenes, a pair of plots are presented. The first compares the parallel measured pairs to identity line $(y=x)$ and the second one shows the difference between the samples (no scrubber - scrubber) against the average between the samples. The dashed black line marks zero, the blue line the mean difference and the dashed blue lines the $95 \%$ limit of agreement. The offset of the mean difference of the samples to zero is a measure of the bias between the two sampling methods. The green regression line shows a possible dependency between the difference of the sample method and their sampled average concentration. All units are given in $\mu \mathrm{g} \mathrm{m}^{-3}$.

Table 5. Ambient total sesquiterpene concentrations were found only during summer months and at the upper part of the canopy. Values are given as mean and standard deviation (SD) in $\mu \mathrm{g} \mathrm{m} \mathrm{m}^{-3}$.

\begin{tabular}{ccccccc}
\hline \multirow{2}{*}{ height } & \multicolumn{2}{c}{ June 2010 } & \multicolumn{2}{c}{ July 2010} & \multicolumn{2}{c}{ August 2010} \\
& mean & SD & mean & SD & mean & SD \\
\hline $20 \mathrm{~m}$ & 0.02 & 0.01 & 0.04 & 0.03 & 0.02 & 0.009 \\
$16 \mathrm{~m}$ & & & 0.71 & 1.1 & 0.77 & 1.1 \\
\hline
\end{tabular}

\section{Discussions}

In general, the values we present here fit into the picture of the reported ambient isoprene and monoterpene concentrations. Such ambient concentrations range from 2 to $5 \mu \mathrm{g} \mathrm{m}^{-3}$ for isoprene and and 10 to $18 \mu \mathrm{g} \mathrm{m}^{-3}$ for monoterpenes in boreal forest ecosystems (Hakola et al., 2000; Rinne et al., 2000; Räisänen et al., 2009). Further ambient terpene concentrations were reported for Greece (Harrison et al., 2001), the Amazon (Rinne et al., 2002), Duke Forest and Oak Ridge in USA (Stroud et al., 2005; Fuentes et al., 2007), where Oak Ridge employed the highest isoprene mixing ratios among the sites noted here. 

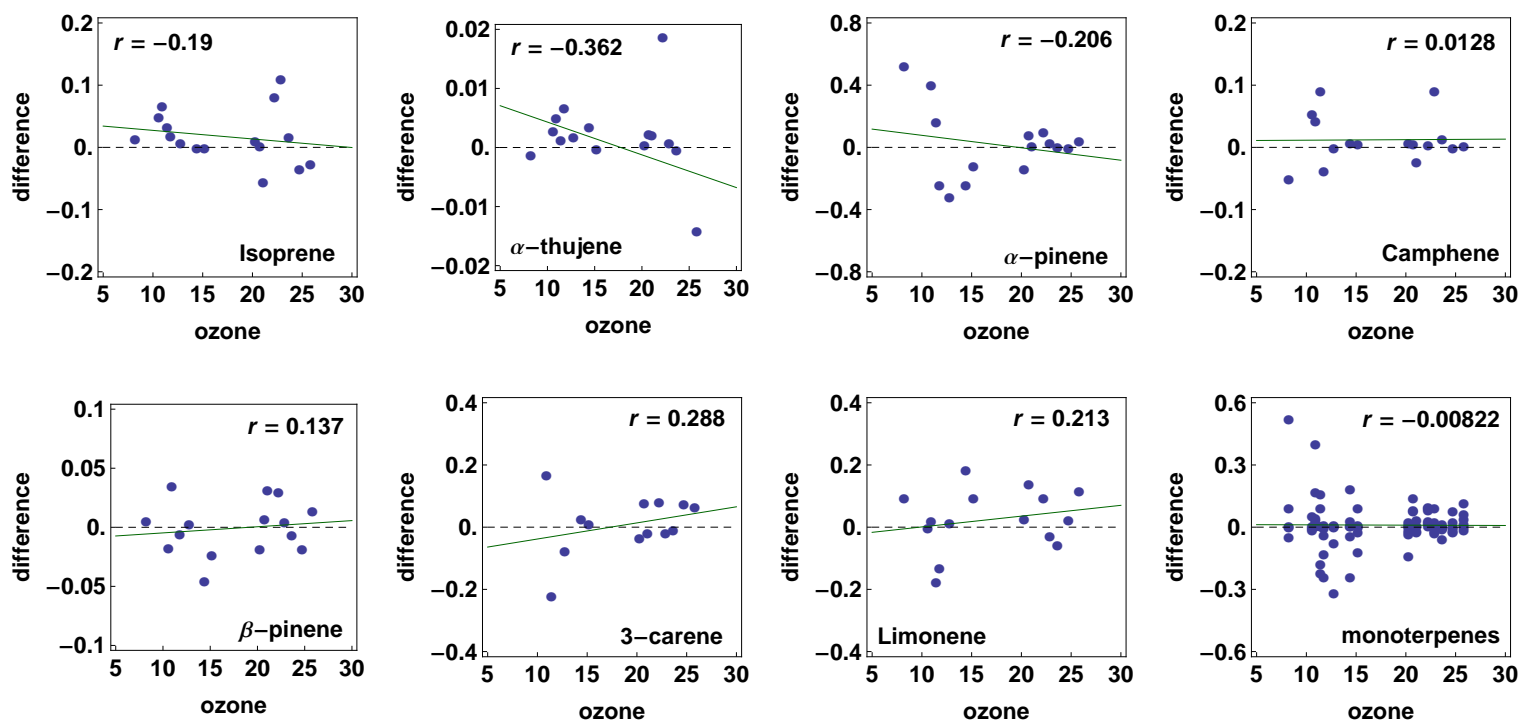

Fig. 7. Relation between atmospheric ozone mixing ratio and the difference between the samples. As the measurements were conducted on two heights, the ozone mixing ratios are clustered. The lower mixing ratios were measured inside and the higher mixing ratios above the canopy. The correlations $r$ between the differences and the ozone mixing ratios are small and the green linear trend lines are included to visually accentuate the correlations. The unit for the difference is given in $\mu \mathrm{g} \mathrm{m}^{-3}$ and for the ozone mixing ratio in ppbv.

Table 6. Selection of ambient BVOC concentrations $\left(\mu \mathrm{g} \mathrm{m}^{-3}\right)$ reported in the literature for several forest ecosystems. If needed, volume mixing ratios have been converted by taking the temperature and air pressure of the measurement period reported into account (cf. Seinfeld and Pandis (2006)) . avg = mean value, med = median value, $\max =$ maximal value of the measurements reported

\begin{tabular}{|c|c|c|c|c|}
\hline Location & isoprene & monoterpenes & Date & References \\
\hline \multicolumn{5}{|c|}{ Boreal } \\
\hline \multirow[t]{8}{*}{ Hyytiälä, Finland } & & $5.15(\operatorname{avg}), 10(\max )$ & 2000-2007 & Hakola et al. (2009) \\
\hline & $0.1-0.3$ & $0.4-4$ & April 2005 & Eerdekens et al. (2009) \\
\hline & $0.6(\operatorname{med}), 1(\max )$ & 1.7(med), 3.3(max) & Summer 2006/2007 & Lappalainen et al. (2009) \\
\hline & $0.2(\mathrm{med}), 0.3(\max )$ & $0.9(\mathrm{med}), 1.7(\max )$ & Winter 2006/2007 & \\
\hline & $0.3(\operatorname{avg}), 1.2(\max )$ & $3(\operatorname{avg}), 15(\max )$ & July 2004 & Rinne et al. (2005) \\
\hline & & $0.2-2.5$ & 37 m, August 1998 & Rinne et al. (2000) \\
\hline & & $0.8-2.8$ & $19.5 \mathrm{~m}$, August 1998 & \\
\hline & & $2.5-3.5$ & 2 m, August 1998 & \\
\hline Huhus, Finland & & $5(\operatorname{avg}), 12(\max )$ & June-September 2003 & Räisänen et al. (2009) \\
\hline Pötsönvaara, Finland & $0.9-4.7$ & $9.5-18$ & April-October 1997, 1998 & Hakola et al. (2000) \\
\hline \multicolumn{5}{|c|}{ Hemiboreal } \\
\hline \multirow[t]{2}{*}{ Järvselja, Estonia } & $1-7$ & $10-40$ & Spring and Summer 2010 & this work \\
\hline & $0.33-0.56$ (med) & $2-8$ (med) & Oct. 2009-Sep. 2010 & this work \\
\hline \multicolumn{5}{|c|}{ Temperate } \\
\hline Michigan, USA & $7(\operatorname{avg}), 22.7(\max )$ & 1.7(avg), 6.1(max) & Summer 2008 & Mielke et al. (2010) \\
\hline Jülich, Germany & $5.5(\mathrm{avg}), 30(\max )$ & 1.4(avg), 8.2(max) & July 2003 & Spirig et al. (2005) \\
\hline Duke Forest, USA & $4.2-6$ & $1.7-4.4$ & July 2003 & Stroud et al. (2005) \\
\hline Oak Ridge, USA & $14-42$ & 3-9 & July 1999 & Fuentes et al. (2007) \\
\hline \multicolumn{5}{|c|}{ Mediterranean } \\
\hline Castelpoziano, Italy & $0.4-0.7$ & $0.6-1.2$ & May-June 2007 & Davison et al. (2009) \\
\hline Agrafa Mountains, Greece & $4.2(\operatorname{avg}), 22(\max )$ & $5(\operatorname{avg}), 28(\max )$ & July-August 1997 & Harrison et al. (2001) \\
\hline \multicolumn{5}{|c|}{ Tropical } \\
\hline $\begin{array}{l}\text { Floresta Nacional do } \\
\text { Tapajos, Brazil }\end{array}$ & 5.5(avg), 11(max) & $0.3(\mathrm{avg}), 0.7(\max )$ & July 2000 & Rinne et al. (2002) \\
\hline
\end{tabular}


Table 7. Relative bias and the precision of the bias estimate. Positive bias values indicate a loss compared to the sample using ozone removal and negative values a gain. The fraction of random error (FRE) contributing to the bias estimate how much of the difference between the parallel samples may be explained by random error. The slope and P-values refer to the linear trend lines in Fig. 6.

\begin{tabular}{lccccc}
\hline & bias $\%$ & precision $\%$ & FRE $\%$ & slope & P-value \\
\hline isoprene & 1.1 & 0.087 & 1.8 & 0.178 & $>0.03$ \\
$\alpha$-thujene & 0.19 & 0.00029 & 0.32 & 0.117 & $>0.5$ \\
$\alpha$-pinene & 1.6 & 0.34 & 11 & 0.00765 & $>0.9$ \\
camphene & 1.2 & 0.0097 & 1.8 & -0.102 & $>0.4$ \\
$\beta$-pinene & -0.075 & 0.0034 & 1.1 & 0.0605 & $>0.6$ \\
3-carene & 0.33 & 0.18 & 8.1 & -0.437 & $>0.03$ \\
limonene & 2.5 & 0.065 & 4.9 & -0.289 & $>0.002$ \\
all monoterpenes & 0.96 & 0.016 & 0.97 & -0.057 & $>0.1$ \\
\hline
\end{tabular}

During spring and summer, our measurements resulted in isoprene values that ranged from 1 to $7 \mu \mathrm{g} \mathrm{m}^{-3}$ and the monoterpene concentrations varied in the same time between 10 and $40 \mathrm{\mu g} \mathrm{m}^{-3}$ if the extreme values measured in July 2010 were excluded. Given reported maximal values for boreal forests (Räisänen et al., 2008, 2009; Eerdekens et al., 2009) the numbers reported here are slightly higher. Hakola et al. (2009) reported as well yearly and monthly averages of monoterpene concentrations which are reflected by our values, if taken out the exceptional July measurements. Overall the hemiboreal forest ecosystem employ slightly larger ambient monoterpene concentrations than the boreal forest and clearly larger than temperate forests where less monoterpene emitting tree species are present. For isoprene, the hemiboreal forest show slightly larger ambient concentrations than the boreal forest but is clearly below the temperate forest concentrations (Table 5).

\subsection{Seasonal variation of the ambient terpene concentrations}

The seasonal variability of both isoprene and monoterpene concentrations in the canopy is high, as expected from variability of plant physiological activity. Wintertime values reflect the lowest and the summertime values the highest biogenic activity. Our measurements support the idea that throughout the year the biogenic source attribution of individual monoterpene compounds changes substantially.

The concentrations for isoprene in winter, spring and autumn remained quite similar even though the temperatures, state of the surface (snow cover in winter, flood in spring) and the physiological conditions of contributing tree species changed substantially during those periods. The deciduous trees lost their leaves and also reached bud burst and developed new foliage causing changes in the light and temperature environment within the forest canopy. However, such dramatic environmental changes, impacting on the biogenic sources and the chemical sinks during daytime, did not lead to substantial changes in ambient isoprene concentrations during most time of the year. Interestingly, the isoprene con- centrations during January were larger than in October and April. That might be due to a low chemical sink and possible anthropogenic influences, that have been reported (Reimann et al., 2000). Such anthropogenic sources are mainly the combustion and evaporation of fossil fuels as well as biomass burning (Reimann et al., 2000; Theloke and Friedrich, 2007; Cai and Xie, 2009).

In contrast, the summer months (June, July and August) showed a very large heterogeneity in the isoprene concentrations increasing up to 7-fold as compared to the rest of the year. That pattern was found consistently over the vertical gradient measured and suggests that the activity of the biogenic sources is largely increased throughout the canopy and follows basically an asymmetric seasonal variation (Niinemets et al., 2010c). The maximum of the BVOC emissions is out of phase with the solar cycle and stronger in the second half of the year.

The ambient monoterpene concentrations followed as well the asymmetric seasonal pattern and employed the highest concentrations during summer. However, that pattern was not consistent over the spatial distribution within the canopy and will be discussed below. Monoterpenes dominated the terpene trace gas concentrations in the forest air over the whole year. When calculating the mean isoprene and monoterpene concentrations during the summer months, monoterpene concentration exceeded the isoprene concentration 6fold. During winter, spring and autumn, the monoterpene concentration dominated even more and exceeded the isoprene concentration 12-fold.

Given the tree species distribution at the measurement site (Noe et al., 2010), the loss of the leaves from the fraction of deciduous trees and, by that a change in sources of both, monoterpenes and isoprene, led to a change of the ambient terpene composition. While the monoterpene concentration remained dominated by biogenic sources there might be anthropogenic contributions to isoprene during winter time. We can not proof that with our data and that was not the intention to do so, but investigating the source attribution is a future task to better understand the role of the annual changes 
of the hemiboreal ecosystems and their impact on the atmospheric state and feedbacks thereof.

\subsection{Vertical variation through the canopy}

Light availability discriminates the most the activity of the biogenic sources and the chemical sinks within the forest canopy during daytime. Up to today, information on vertical variation of BVOC is scarce (Fuentes et al., 2007; Eerdekens et al., 2009). Recent studies showed (Noe et al., 2010; Fuentes et al., 2007; Eerdekens et al., 2009) that reactive trace gas concentrations are substantially smaller within the canopy under shade conditions than above the canopy in sunlight. Furthermore, Eerdekens et al. (2009) reported larger terpene concentrations at night time but beside a possible loss of activity in the chemical sink when there is no or low light there are the possibilities that the cease of turbulent mixing and a shallow nocturnal boundary layer are present. All these processes will contribute to a concentration change. However, we assumed that the boundary layer was not changing substantially during our $2-2.5 \mathrm{~h}$ midday measurements and the changes seen in BVOC ambient concentrations are bound to source strength and attribution, activity of the chemical sink and transport within the canopy.

While our measured isoprene concentration did not change very much, the total monoterpene concentration was increased by a factor of two or three, depending on the height in the canopy. This accumulation of monoterpenes within the lower 4-8 $\mathrm{m}$ inside the canopy may be explained by several means. As the available ozone and $\mathrm{NO}_{\mathrm{x}}$ concentrations are reduced by $50 \%$ inside the canopy (Noe et al., 2010), the chemical sink activity should be reduced. On the other hand, the mixing inside the canopy should be as well reduced. Unfortunately, we have no micrometeorological measurements covering the whole period reported here. From our campaigns in 2008 and 2009, we can give an estimate of the typical friction velocities $u_{*}$ during summer when the canopy is densely closed with leaves. At $2 \mathrm{~m}$ height inside the canopy we measured a median friction velocity of $0.08 \mathrm{~m} \mathrm{~s}^{-1}$ while on top of the canopy at $20 \mathrm{~m}$ height we found a median of $0.4 \mathrm{~m} \mathrm{~s}^{-1}$. That situation is further supported by the measurements of the horizontal wind speed (Fig. 2). However, to conclusively prove the scenario we described here, we would need to conduct a comparison between the actual reaction rates, transport and dilution together with the strengths of possible sources.

Beside trees, also the soil is a source of monoterpenes and high concentrations have been reported for soil under Pinus sylvestris L., Betula pendula L. and Picea abies L. (Isidorov et al., 2010; Aaltonen et al., 2011). Soil airspace concentrations have been reported to be about a factor of 1000 larger than in ambient air (Smolander et al., 2006) and a contribution of monoterpenes emitted from soil to the concentration in forest air is a likely process.
The general pattern of the vertical terpene concentration is seen by the yearly median values. Isoprene concentrations remained almost constant over the canopy height and employed the largest variations at $16 \mathrm{~m}$ height. There is the main part of photosynthesizing foliage located and the highest source activity. At $20 \mathrm{~m}$ in full sunlight, the chemical sink and the mixing is stronger and thus the possible isoprene concentrations are smaller.

The median monoterpene concentration tends to be highest at the forest floor until $4 \mathrm{~m}$ height and then decreases by a factor of four until the top of the canopy. Largest variations were found at the forest floor and at $16 \mathrm{~m}$ height. This can be seen as an indication that soil and litter is an important monoterpene source near the forest floor and the plant foliage source is strongest at $16 \mathrm{~m}$ where the largest amount of leaves are located in summer. At $20 \mathrm{~m}$, again the stronger oxidation processes and mixing should lead to lower ambient concentrations.

\subsection{Temporal and spatial variation in the relative monoterpene contribution}

The main contributing monoterpenes changed over time and space within the forest canopy. The dominant compound in the lower canopy was $\alpha$-pinene while at the top of the canopy limonene took that role. An exception of this pattern was the month of January, when the $\Delta^{3}$-carene contribution dominated at all heights. A possible explanation is the logging activity which took place in winter, even though, not in the direct vicinity of the measurement site. The Järvselja experimental Forestry Station covers about 11000 ha and is a managed forest. Logging activity and storage of logs in that area is likely. From a recent study (Noe et al., 2010) we know that $\Delta^{3}$-carene is the main compound emitted from P. abies at our site and it shared up to $14 \%$ of the spruces resin monoterpene content. Because of that, $\Delta^{3}$-carene emissions from freshly cut and stored logs in the area are a likely source, at least during wintertime.

Taking the lifetime and reaction rate constants of $\alpha$-pinene and limonene into account (Atkinson, 2000), the temporal and spatial relative contribution pattern give some informations on the change in the activity in the biogenic sources. Above the canopy the chemical loss of limonene should be larger due to its reaction rate which allows a faster decay as compared to $\alpha$-pinene. As it was found to be the most abundant monoterpene in ambient air at $20 \mathrm{~m}$, there has to be a large source activity. One explanation during the summer months might be an increased limonene emission flux under heat stress as reported for Pinus sylvestris and Picea abies (Turtola et al., 2003). A further support to this viewpoint is the fact that we found only in June to August sesquiterpenes on the two top layers in the canopy. As these are also stress indicators, their occurrence may be bound to the high temperatures and light impacts on the foliage. However, a recent study did not reveal the same pattern in leaf level 
monoterpene fluxes during summer (Noe et al., 2010) measured at the same site. In that sense, a simple link between leaf level fluxes and ambient concentrations in a system with multiple influencing factors might hold only temporarily.

The monoterpene concentrations inside the forest, especially near the forest floor, showed a clear contribution pattern. This pattern was present even in early spring with snow cover and flooding after the snow melted away. Comparing the measurement of the monoterpene contribution in ambient air to soil and litter fluxes (Fig. 5 and Table 4) the fractions we found for $\alpha$-pinene and limonene resemble most closely the soil efflux found in the boreal forest (Aaltonen et al., 2011). Even though soil and litter efflux were found to be slow as compared to the leaf fluxes (Noe et al., 2010) a weak mixing and low windspeed (Fig. 2) during summer with a very dense foliage on top could lead to monoterpene accumulation inside the canopy.

Yet, monoterpene contributions from soil or litter are scarcely investigated. Possible sources are soil microbes (Ramirez et al., 2010) and the litter (Gray et al., 2010; Isidorov et al., 2010). Hayward et al. (2001) reported also differences in VOC fluxes according to the depth of the soil. However, the comparison with litter and soil flux samples (Table 4) suggests that there is a large variability in litter and soil monoterpene fluxes. In our case, the spruce resin is another potential source contributing to the ambient concentrations measured from early spring to autumn. As resin is located within the litter and the trunks, there is a substantial spatial cover within the forest canopy for such monoterpene contributions to the ambient concentration.

\subsection{Impacts of polluted environments during sampling of ambient BVOC}

Sampling of BVOC from polluted environments was recently reviewed by Niinemets et al. (2011) rather generally. The main influences such as sample technique, used adsorbent materials, impacts of reactive trace gases, most prominently ozone, and ozone trapping techniques were discussed. The general picture can be summarized as follows: While the ozone scrubbers are usually placed in the first place of the sample line reported effects (Fick et al., 2001; Helmig, 1997) of adsorption/desorption processes in the scrubber line will effect on the BVOC sampling. Even a complete loss of some mono- and sesquiterpenes in ozone-free air has been shown (Arnts, 2008; Pollmann et el., 2005). The use of scrubbers is usually beneficial when Tenax adsorption materials are used and while sampling from enclosure systems but might lead to artifacts in case of sampling ambient air.

A less prominently discussed point is the situation within the sample cartridge where the adsorption of the BVOC to, in our case carbon surfaces, take place. It was already noted by Calogirou et al. (1996) that the terpene-ozone gas-phase reaction rate constants alone can not fully explain the terpene losses and the authors suggest a combination of heteroge- neous reaction rates according to the adsorption of the $\mathrm{BVOC}$ sampled. A study of the impact of ozone and limonene on activated carbon filters (Metts, 2007) revealed that, indeed, heterogeneous reactions of limonene on the adsorbent material with ozone took place. In the same study, it was reported that after 48 hours of exposure to high ozone ( $8.95 \mathrm{ppmv})$ mixing ratios about $58 \%$ and of the originally adsorbed limonene was recovered from the filter material. Short term exposure $(30 \mathrm{~min})$ to $5.8 \mathrm{ppmv}$ ozone had a recovery of $95 \%$ of limonene adsorbed on active carbon filters.

Artifact formation for several adsorbent materials under ozone impact was also discussed by Lee et al. (2006). While the Tenax adsorbents showed up to 13 artifacts measuring carbonyl compounds at $100 \mathrm{ppbv}$ ozone mixing ratio, Carbopack B showed 7 artifacts and Carbopack X none. Even though the study does not focus on terpenes, the carbon backbones of the measured compounds ranged from $\mathrm{C} 5$ to $\mathrm{C} 13$ carbon skeletons and covered the isoprene and monoterpene molecule sizes.

The relative bias between the two methods of sampling we applied here ranged between $-0.08-2.5 \%$ and was estimated by the hypothesis, that the difference between both sample methods is normally distributed and caused by chemical loss of terpenes while sampling. Therefore, we have to assume that the other sources of bias and random error introduced by subsequent GC-MS analysis and peak integration are conserved for both sampling methods and because of that drop out when calculating differences. However, that last assumption can not be assured to $100 \%$ and therefore, the bias estimated might reflect as well other impacts beside the chemical degradation of terpenes while sampling.

As expected, the largest bias in terms of sampling loss was found for limonene $(2.5 \%)$ as it employs the fastest reaction rate among the terpenes determined. Followed by $\alpha$-pinene $(1.6 \%)$ and camphene $(1.2 \%)$ which employ the slowest ambient reaction rates among the detected monoterpenes. That outcome implies, that there have to be other effects taken into account beside atmospheric terpene-ozone reactions during sampling. Assumed similar concentrations of $\alpha$-pinene and limonene and the same ozone mixing ratios and temperatures, the ambient atmospheric reaction rate of limonene is about a factor of 5 larger than for $\alpha$-pinene and therefore, the loss should reflect that as well. However, we found that the bias of limonene is just a factor of 1.5 larger than for $\alpha$-pinene. The chosen months for the additional measurements have been those where $\alpha$-pinene and limonene were contributing almost with the same amount to the ambient monoterpene concentration (Fig. 5). Ozone mixing ratios were close to the mean measured over the whole season and the same for both sample methods during the parallel sampling. The ambient concentrations of $\alpha$-pinene and limonene differed about $25 \%$ with higher concentrations of $\alpha$-pinene. That might reduce the factor to favor loss of limonene to 3.5 but that is still substantially larger compared to the factor in the bias we found. One candidate to explain the weaker losses 
during sampling might be the heterogenous reaction scheme as reported (Metts, 2007).

The effect of random error on the relative bias estimate is described by the precision of the limits of agreement scaled to the standard deviations of the differences between both sampling methods. The range spans between 0.3 and $11 \%$. Overall, we can state that random effects play a minor role in determining the bias.

The linear regression on the differences showed that only the bias of $\alpha$-pinene can be handled as a constant shift and graded to be independent of the ambient concentrations. For $\alpha$-thujene, $\beta$-pinene and as well isoprene, the slope is positive and indicating that the bias will most probably grow with growing ambient concentrations. $\beta$-pinene is, however, still rather near to a constant shift. Camphene, $\Delta^{3}$-carene, limonene, and the combined data set of all monoterpenes showed a negative slope, indicating that the bias will be smaller the larger the ambient concentrations are.

If the differences are related to the ambient ozone mixing ratios (Fig. 7) the Pearson correlation coefficients are small and to be at the safe side we do not draw strong conclusions about a relation between bias and ozone mixing ratios in the case presented here. However, positive coefficients were found for $\beta$-pinene, $\Delta^{3}$-carene, and limonene indicating a growing bias by growing ambient ozone mixing ratios. As we have measured on $0 \mathrm{~m}$ and $20 \mathrm{~m}$ height and ozone mixing ratios are found highest above the canopy we can see another pattern in Fig. 7. The differences were mostly smaller under higher ozone mixing ratios which is contrary to the exceptions. But given the fact, that the overall ambient concentrations are lower for monoterpenes above the canopy (Table 3) this may just reflect that situation.

Taking the relative contribution of monoterpenes within the canopy (Fig. 5) into account the bias in the lower part of the canopy will be smaller as the main compound there is $\alpha$ pinene. The highest bias due to ozone losses will occur on top of the canopy during summer when limonene is dominating the terpene mixture in ambient air. As the ozone mixing ratio and the temperature affecting as well the overall reaction of limonene and ozone while sampling, a final conclusion can not be made here.

In our case, the application of the ozone scrubber leaded to a $100 \%$ loss of sesquiterpenes which might be due to the change in the inlet system. Due to that we are not able to give a loss rate for our system and we rely on the work Pollmann et el. (2005) that let us estimate about $50 \%$ loss while sampling without ozone removal. However, sesquiterpenes were not the main focus of our work but we graded their detection during summer notable.

\section{Conclusions}

We found clear seasonal and spatial pattern of isoprene and monoterpene ambient concentrations within the forest canopy. While the variation in the isoprene concentration can mainly be explained by the biogenic emission from deciduous trees, the monoterpene concentrations showed the largest values and variations above the forest floor.

During summertime, very large stress related emissions from the biogenic sources led to large ambient concentrations despite of the also high oxidation sink for terpenes. Especially monoterpene concentrations were the dominant terpenes in forest canopy air.

The relative contribution of monoterpenes let us propose several possible sources within the canopy. The main sources during the growing season are the foliage and under high temperature the stress related emissions can temporarily dominate the source capacity. The forest floor (soil and litter) is a strong source, especially for $\alpha$-pinene throughout the year and resins may contribute as well in that temporal range. The measurement in January was dominated by $\Delta^{3}$-carene and anthropogenic sources may play a role during wintertime.

We can conclude that the lower canopy is weakly mixed and rather stable during spring and summer leading to at least two clearly distinct layers within the canopy. Oxidative degradation processes inside the canopy may play a more prominent role during that time. In autumn and winter the patterns resemble more to the situation of the boreal forest with coniferous trees as main contributors of biogenic hydrocarbons and a rather open canopy structure allowing stronger mixing.

Predictions of BVOC fluxes by means of vegetation maps that grade the hemiboreal area as temperate mixed forests are likely to overestimate the isoprene and underestimate the monoterpene fluxes to the boundary layer.

Acknowledgements. We thank Pille Randjärv and Lea Noe for their help collecting the samples during the measurement campaigns. We further thank Beate Noe for her help in analyzing the chromatograms. We thank Hermanni Aaltonen for his comments on forest floor monoterpene emissions from boreal soils given at the 2nd Nordic-Baltic BACCI VOC Workshop (11-12 October 2010, Puurmani, Estonia). Financial support by the Estonian Ministry of Education and Science (Grant SF1090065s07) and the European Commission through European Regional Fund (the Center of Excellence in Environmental Adaptation) are gratefully acknowledged.

Edited by: J. Rinne 


\section{References}

Aaltonen, H., Pumpanen, J., Pihlatie, M., Hakola, H., Hellèn, H., Kulmala, L., Vesala, T., and Bäck, J.: Boreal pine forest floor biogenic volatile organic compound emissions peak in early summer and autumn, Agr. Forest Meteorol., 151, 682-691, 2011.

Arneth, A. and Niinemets, Ü.: Induced BVOCs: how to bug our models?, Trends Plant Sci., 15, 118-125, 2010.

Arneth, A., Monson, R. K., Schurgers, G., Niinemets, Ü., and Palmer, P. I.: Why are estimates of global terrestrial isoprene emissions so similar (and why is this not so for monoterpenes)?, Atmos. Chem. Phys., 8, 4605-4620, doi:10.5194/acp-8-46052008, 2008.

Arneth, A., Harrison, S. P., Zaehle, S., Tsigaridis, K., Menon, S., Bartlein, P. J., Feichter, J., Korhola, A., Kulmala, M., O'Donnell, D., Schurgers, G., Sorvari, S., and Vesala, T.: Terrestrial biogeochemical feedbacks in the climate system, Nat. Geosci., 3, 525-532, doi:10.1038/ngeo905, 2010.

Arnts, R. R.: Reduction of biogenic VOC sampling losses from ozone via trans-2-butene addition, Environ. Sci. Technol., 42, 7663-7669, 2008.

Atkinson, R.: Atmospheric chemistry of VOCs and $\mathrm{NO}_{\mathrm{x}}$, Atmos. Environ., 34, 2063-2101, doi:10.1016/S1352-2310(99)00460-4, 2000.

Atkinson, R., Aschmann, S. M., and Arey, J.: Rate constants for the gas-phase reactions of $\mathrm{OH}$ and $\mathrm{NO}_{3}$ radicals and $\mathrm{O}_{3}$ with sabinene and camphene at $296 \pm 2 \mathrm{~K}$, Atmos. Environ. A-Gen., 24, 2647-2654, doi:10.1016/0960-1686(90)90144-C, 1990.

Bland, J. M., and Altman, D. G.: Measuring agreement in method comparison studies, Stat. Methods Med. Res., 8, 135-160, 1999

Cai, H. and Xie, S. D.: Tempo-spatial variation of emission inventories of speciated volatile organic compounds from onroad vehicles in China, Atmos. Chem. Phys., 9, 6983-7002, doi:10.5194/acp-9-6983-2009, 2009.

Calogirou, A., Larsen, B. R., Brussol, C., Duane, M., and Kotzias, D.: Decomposition of terpenes by ozone during sampling on Tenax, Anal. Chem., 68, 1499-1506, 1996.

Ciccioli, P., Brancaleoni, E., Possanzini, M., Brachetti, A., and Di Palo, C.: Physico-Chemical Behaviour of Atmospheric Pollutants, 62-73, D. Reidel Publishing Co., Dordrecht, The Netherlands, 1984.

Copolovici, L., Filella, I., Llusia, J., Niinemets, Ü., and Peñuelas, J.: The capacity for thermal protection of photosynthetic electron transport varies for different monoterpenes in Quercus ilex, Plant Physiol., 139, 485-496, 2005.

Copolovici, L., Kännaste, A., and Niinemets, Ü.: Gas Chromatography-mass spectrometry method for determination of monoterpene and sesquiterpene emissions from stressed plants, Stud. Univ. Babes-Bol., 54, 329-339, 2009.

Davison, B., Taipale, R., Langford, B., Misztal, P., Fares, S., Matteucci, G., Loreto, F., Cape, J. N., Rinne, J., and Hewitt, C. N.: Concentrations and fluxes of biogenic volatile organic compounds above a Mediterranean macchia ecosystem in western Italy, Biogeosciences, 6(8), 1655-1670, doi:10.5194/bg-6-16552009, 2009.

Eerdekens, G., Yassaa, N., Sinha, V., Aalto, P. P., Aufmhoff, H., Arnold, F., Fiedler, V., Kulmala, M., and Williams, J.: VOC measurements within a boreal forest during spring 2005: on the occurrence of elevated monoterpene concentrations during night time intense particle concentration events, Atmos. Chem. Phys.,
9, 8331-8350, doi:10.5194/acp-9-8331-2009, 2009.

Fick, J., Pommer, L., Andersson, B., and Nilsson, C.: Ozone removal in the sampling of parts per billion levels of terpenoid compounds: An evaluation of different scrubber materials, Environ. Sci. Technol., 35, 1458-1462, 2001.

Forkel, R., Klemm, O., Graus, M., Rappenglück, B., Stockwell, W. R., Grabmer, W., Held, A., Hansel, A., and Steinbrecher, R.: Trace gas exchange and gas phase chemistry in a Norway spruce forest: a study with a coupled 1-dimensional canopy atmospheric chemistry emission model, Atmos. Environ., 40, 28-42, doi:10.1016/j.atmosenv.2005.11.070, 2006.

Fuentes, J., Wang, D., Bowling, D., Potosnak, M., Monson, R., Goliff, W., and Stockwell, W.: Biogenic hydrocarbon chemistry within and above a mixed deciduous forest, J. Atmos. Chem., 56, 165-185, 2007.

Gray, C. M., Monson, R. K., and Fierer, N.: Emissions of volatile organic compounds during the decomposition of plant litter, J. Geophys. Res., 115, G03015, doi:10.1029/2010JG001291, 2010.

Guenther, A., Karl, T., Harley, P., Wiedinmyer, C., Palmer, P. I., and Geron, C.: Estimates of global terrestrial isoprene emissions using MEGAN (Model of Emissions of Gases and Aerosols from Nature), Atmos. Chem. Phys., 6, 3181-3210, doi:10.5194/acp-63181-2006, 2006.

Hakola, H., Laurila, T., Rinne, J., and Puhto, K.: The ambient concentrations of biogenic hydrocarbons at a Northern European, boreal site, Atmos. Environ., 34, 4971-4982, 2000.

Hakola, H., Tarvainen, V., Laurila, T., Hiltunen, V., Hellén, H., and Keronen, P.: Seasonal variation of VOC concentrations above a boreal coniferous forest, Atmos. Environ., 37, 1623-1634, 2003.

Hakola, H., Hellén, H., Tarvainen, V., Bäck, J., Patokoski, J., and Rinne, J.: Annual variations of atmospheric VOC concentrations in a boreal forest., Boreal Environ. Res., 14, 722-730, 2009.

Harrison, D., Hunter, M. C., Lewis, A. C., Seakins, P. W., Bonsang, B., Gros, V., Kanakidou, M., Touaty, M., Kavouras, I., Mihalopoulos, N., Stephanou, E., Alves, C., Nunes, T., and Pio, C.: Ambient isoprene and monoterpene concentrations in a Greek fir (Abies borisii-regis) forest. Reconciliation with emissions measurements and effects on measured $\mathrm{OH}$ concentrations, Atmos. Environ., 35, 4699-4711, 2001.

Hayward, S., Muncey, R. J., James, A. E., Halsall, C. J., and Hewitt, C. N.: Monoterpene emissions from soil in a Sitka spruce forest, Atmos. Environ., 35, 4081-4087, 2001.

Helmig, D.: Ozone removal techniques in the sampling of atmosphericvolatile organic trace gases, Atmos. Environ., 31, 36353651, 1997.

Holzinger, R., Lee, A., Paw, K. T., and Goldstein, U. A. H.: Observations of oxidation products above a forest imply biogenic emissions of very reactive compounds, Atmos. Chem. Phys., 5, 67-75, doi:10.5194/acp-5-67-2005, 2005.

Holzinger, R., Lee, A., McKay, M., and Goldstein, A. H.: Seasonal variability of monoterpene emission factors for a ponderosa pine plantation in California, Atmos. Chem. Phys., 6, 1267-1274, doi:10.5194/acp-6-1267-2006, 2006.

Intergovernmental Panel on Climate Change: Fourth Assessment Report: Climate Change 2007: The AR4 Synthesis Report, Geneva: IPCC, available at: http://www.ipcc.ch/ipccreports/ ar4-wg1.htm, last access: 3 August 2010, 2007.

Isidorov, V. A., Smolewska, M., Purzyńska-Pugacewicz, A., and Tyszkiewicz, Z.: Chemical composition of volatile and extractive 
compounds of pine and spruce leaf litter in the initial stages of decomposition, Biogeosciences, 7, 2785-2794, doi:10.5194/bg7-2785-2010, 2010.

Kanakidou, M., Seinfeld, J. H., Pandis, S. N., Barnes, I., Dentener, F. J., Facchini, M. C., Van Dingenen, R., Ervens, B., Nenes, A., Nielsen, C. J., Swietlicki, E., Putaud, J. P., Balkanski, Y., Fuzzi, S., Horth, J., Moortgat, G. K., Winterhalter, R., Myhre, C. E. L., Tsigaridis, K., Vignati, E., Stephanou, E. G., and Wilson, J.: Organic aerosol and global climate modelling: a review, Atmos. Chem. Phys., 5, 1053-1123, doi:10.5194/acp-51053-2005, 2005.

Karl, T., Potosnak, M., Guenther, A., Clark, D., Walker, J., Herrick, J. D., and Geron, C.: Exchange processes of volatile organic compounds above a tropical rain forest: implications for modeling tropospheric chemistry above dense vegetation, J. Geophys. Res., 109, D18306, doi:10.1029/2004JD004738, 2004.

Kulmala, M., Suni, T., Lehtinen, K. E. J., Dal Maso, M., Boy, M., Reissell, A., Rannik, Ü, Aalto, P., Keronen, P., Hakola, H., Bäck, J., Hoffmann, T., Vesala, T., and Hari, P.: A new feedback mechanism linking forests, aerosols, and climate, Atmos. Chem. Phys., 4, 557-562, doi:10.5194/acp-4-557-2004, 2004.

Lappalainen, H. K., Sevanto, S., Bäck, J., Ruuskanen, T. M., Kolari, P., Taipale, R., Rinne, J., Kulmala, M., and Hari, P.: Daytime concentrations of biogenic volatile organic compounds in a boreal forest canopy and their relation to environmental and biological factors, Atmos. Chem. Phys., 9, 5447-5459 doi:10.5194/acp-9-5447-2009, 2009.

Lee, J. H., Batterman, S. A., Jia, C., and Chernyak, S.: Ozone Artifacts and Carbonyl Ceasurements Using Tenax GR, Tenax TA, Carbopack B, and Carbopack X Adsorbents, J. Air \& Waste Manage. Assoc., 56, 1503-1517, 2006.

Lyubovtseva, Y. S., Sogacheva, L., Dal Maso, M., Bonn, B., Keronen, P., and Kulmala, M.: Seasonal variations of trace gases, meteorological parameters, and formation of aerosols in boreal forests., Boreal Environ. Res., 10, 493-510, 2005.

Mayrhofer, S., Teuber, M., Zimmer, I., Louis, S., Fischbach, R. J., and Schnitzler, J.-P.: Diurnal and seasonal variation of isoprene biosynthesis-related genes in grey poplar leaves, Plant Physiol., 139, 474-484, doi:10.1104/pp.105.066373, 2005.

Metts, T. A.: Heterogeneous reactions of ozone and D-limonene on activated carbon, Indoor Air, 17, 362-371, 2007.

Mielke, L. H., Pratt, K. A., Shepson, P. B., McLuckey, S. A., Wisthaler, A., and Hansel, A.: Quantitative Determination of Biogenic Volatile Organic Compounds in the Atmosphere Using Proton-Transfer Reaction Linear Ion Trap Mass Spectrometry, Analyt. Chem., 82, 7952-7957, 2010.

Ng, N. L., Kwan, A. J., Surratt, J. D., Chan, A. W. H., Chhabra, P. S., Sorooshian, A., Pye, H. O. T., Crounse, J. D., Wennberg, P. O., Flagan, R. C., and Seinfeld, J. H.: Secondary organic aerosol (SOA) formation from reaction of isoprene with nitrate radicals $\left(\mathrm{NO}_{3}\right)$, Atmos. Chem. Phys., 8, 4117-4140, doi:10.5194/acp-84117-2008, 2008.

Niinemets, Ü.: Responses of forest trees to single and multiple environmental stresses from seedlings to mature plants: past stress history, stress interactions, tolerance and acclimation, Forest Ecol. Manag., 260, 1623-1639, 2010a.

Niinemets, Ü.: Mild versus severe stress and BVOCs: thresholds, priming and consequences, Trends Plant Sci., 15, 145-153, $2010 b$.
Niinemets, Ü., Arneth, A., Kuhn, U., Monson, R. K., Peñuelas, J., and Staudt, M.: The emission factor of volatile isoprenoids: stress, acclimation, and developmental responses, Biogeosciences, 7, 2203-2223, doi:10.5194/bg-7-2203-2010, 2010c.

Niinemets, Ü., Monson, R. K., Arneth, A., Ciccioli, P., Kesselmeier, J., Kuhn, U., Noe, S. M., Peñuelas, J., and Staudt, M.: The leaf-level emission factor of volatile isoprenoids: caveats, model algorithms, response shapes and scaling, Biogeosciences, 7, 1809-1832, doi:10.5194/bg-7-1809-2010, $2010 d$.

Niinemets, Ü., Kuhn, U., Harley, P. C., Staudt, M., Arneth, A., Cescatti, A., Ciccioli, P., Copolovici, L., Geron, C., Guenther, A., Kesselmeier, J., Lerdau, M. T., Monson, R. K., and Peñuelas, J.: Estimations of isoprenoid emission capacity from enclosure studies: measurements, data processing, quality and standardized measurement protocols, Biogeosciences, 8, 22092246, doi:10.5194/bg-8-2209-2011, 2011.

Nilsson, S. G.: Forests in the temperate-boreal transition: natural and man-made features, Ecol. Bull., 46, 61-71, 1997.

Noe, S. M., Copolovici, L., Niinemets, Ü., and Vaino, E.: Foliar limonene uptake scales positively with leaf lipid content: "nonemitting" species absorb and release monoterpenes., Plant Biol., 10, 129-137, 2008.

Noe, S. M., Kimmel, V., Hüve, K., Copolovici, L., PortilloEstrada, M., Püttsepp, Ü., Jõgiste, K., Niinemets, Ü., Hörtnagl, L., and Wohlfahrt, G.: Ecosystem-scale biosphereatmosphere interactions of a hemiboreal mixed forest stand at Järvselja, Estonia, Forest Ecol. Manag., 262, 71-81, doi:10.1016/j.foreco.2010.09.013, 2010.

Pollmann, J., Ortega, J., and Helmig, D.: Analysis of atmospheric sesquiterpenes: Sampling losses and mitigation of ozone interferences, Environ. Sci. Technol., 39, 9620-9629, 2005.

Räisänen, T., Ryyppö, A., and Kellomäki, S.: Impact of timber felling on the ambient monoterpene concentration of a Scots pine (Pinus sylvestris L.) forest, Atmos. Environ., 42, 6759-6766, 2008.

Räisänen, T., Ryyppö, A., and Kellomäki, S.: Monoterpene emission of a boreal Scots pine (Pinus sylvestris L.) forest, Agr. Forest Meteorol., 149, 808-819, 2009.

Ramirez, K., Lauber, C., and Fierer, N.: Microbial consumption and production of volatile organic compounds at the soil-litter interface, Biogeochemistry, 99, 97-107, 2010.

Reimann, S., Calanca, P., and Hofer, P.: The anthropogenic contribution to isoprene concentrations in a rural atmosphere, Atmos. Environ., 34, 109-115, 2000.

Rinne, J., Ruuskanen, T. M., Reissell, A., Taipale R., Hakola, H., and Kulmala, M.: On-line PTR-MS measurements of atmospheric concentrations of volatile organic compounds in a European boreal forest ecosystem, Boreal Environ. Res., 10, 425-436, 2005.

Rinne, H. J. I., Guenther, A. B., Greenberg, J. P., and Harley, P. C.: Isoprene and monoterpene fluxes measured above Amazonian rainforest and their dependence on light and temperature, Atmos. Environ., 36, 2421-2426, 2002.

Rinne, J., Hakola, H., Laurila, T., and Rannik, Ü.: Canopy scale monoterpene emissions of Pinus sylvestris dominated forests, Atmos. Environ., 34, 1099-1107, 2000.

Sabillón, D. and Cremades, L. V.: Diurnal and seasonal variation of monoterpene emission rates for two typical Mediterranean species (Pinus pinea and Quercus ilex) from field measurements- 
relationship with temperature and PAR, Atmos. Environ., 35, 4419-4431, 2001.

Sætersdal, M., Birks, H. J. B., and Peglar, S.: Predicting changes in Fennoscandian vascular-plant species richness as a result of future climatic change, J. Biogeogr., 25, 111-112, 1998.

Schurgers, G., Arneth, A., Holzinger, R., and Goldstein, A. H.: Process-based modelling of biogenic monoterpene emissions combining production and release from storage, Atmos. Chem. Phys., 9, 3409-3423, doi:10.5194/acp-9-3409-2009, 2009.

Seinfeld, J. H. and Pandis, S. N.: Atmospheric Chemistry and Physics, John Wiley and Sons Inc., Hoboken, New Jersey, USA, 2nd edn., 2006.

Smolander, A., Ketola, R. A., Kotiaho, T., Kanerva, S., Suominen, K., and Kitunen, V.: Volatile monoterpenes in soil atmosphere under birch and conifers: effects on soil $\mathrm{N}$ transformations, Soil Biol. Biochem., 38, 3436-3442, 2006.

Spirig, C., Neftel, A., Ammann, C., Dommen, J., Grabmer, W., Thielmann, A., Schaub, A., Beauchamp, J., Wisthaler, A., and Hansel, A.: Eddy covariance flux measurements of biogenic VOCs during ECHO 2003 using proton transfer reaction mass spectrometry, Atmos. Chem. Phys., 5, 465-481, doi:10.5194/acp-5-465-2005, 2005.

Spracklen, D. V., Bonn, B., and Carslaw, K. S.: Boreal forests, aerosols and the impacts on clouds and climate, Philos. T. Roy. Soc. A, 366, 4613-4626, 2008.
Strong, C., Fuentes, J., and Baldocchi, D.: Reactive hydrocarbon flux footprints during canopy senescence, Agr. Forest Meteorol., 127, 159-173, 2004.

Stroud, C., Makar, P., Karl, T., Guenther, A., Geron, C., Turnipseed, A., Nemitz, E., Baker, B., Potosnak, M., and Fuentes, J. D.: Role of canopy-scale photochemistry in modifying biogenic-atmosphere exchange of reactive terpene species: results from the CELTIC field study, J. Geophys. Res., 110, D17303, doi:10.1029/2005JD005775, 2005.

Sun, Z., Copolovici, L., and Niinemets, Ü.: Can the capacity for isoprene emission acclimate to environmental modifications during autumn senescence in temperate deciduous tree species Populus tremula?, J. Plant Res., 125, 263-274, 2012.

Theloke, J. and Friedrich, R.: Compilation of a database on the composition of anthropogenic VOC emissions for atmospheric modeling in Europe, Atmos. Environ., 41, 4148-4160, 2007.

Toome, M., Randjärv, P., Copolovici, L., Niinemets, Ü., Heinsoo, K., Luik, A., and Noe, S. M.: Leaf rust induced volatile organic compounds signalling in willow during the infection, Planta, 232, 235-243, 2010.

Turtola, S., Manninen, A.-M., Rikala, R., and Kainulainen, P.: Drought stress alters the concentration of wood terpenoids in Scots pine and Norway spruce seedlings, J. Chem. Ecol., 29, 1981-1995, 2003. 